\title{
The Nineteenth-Century Molyneux's Boat: Archaeometallurgical Perspective of its Metal Fastenings
}

\author{
M. Bram ${ }^{1} \cdot$ N. Iddan $^{1,2} \cdot$ D. Ashkenazi ${ }^{3} \cdot$ D. Cvikel ${ }^{1,4}$
}

Received: 16 July 2020 / Revised: 31 August 2020 / Accepted: 3 September 2020 / Published online: 22 September 2020

(c) ASM International 2020

\begin{abstract}
The 4.4-m-long vessel designated as Molyneux's boat was built in England in 1836. During its conservation in 2008, metal fastenings were retrieved, and 12 of them were examined by XRF, metallographic and multifocal light microscopy, microindentation hardness measurement and SEM-EDS analysis. The results show the use of manufacturing techniques developed at different times: the copper fastenings were made by traditional methods-intensive hammering to their final shape followed by annealing; the screws and nuts were made of brass containing $36 \mathrm{wt} \% \mathrm{Zn}$ and were probably a post- 1848 product; and the bolt was made of low-carbon steel (produced by the Bessemer process) and shaped by plastic deformation, perhaps through a thread-rolling process. The bolt was galvanized, thus most probably manufactured after 1856 . It appears that the boat was originally built using copper fastenings, and some of which were replaced by galvanized bolts and brass screws during minor refitting.
\end{abstract}

Keywords Boat construction · Brass · Copper $\cdot$ Fastenings $\cdot$ Galvanized steel $\cdot$ Microstructure

\section{Introduction}

All Royal Navy ships were required to carry a certain number of boats: a first-rate warship had six boats, and the number decreased in relation to the size and type of ship [1, p. 80]. The smallest was the jolly boat, pulled by four oars. It was used for various purposes such as running out the kedge, working the ship in narrow waters and taking crew ashore [1, p. 81]. The Molyneux boat was built in England in 1836 [2, p. 33, 3, p. 257] and was the jolly boat of HMS Spartan, a 26-gun, sixth-rate frigate of the Royal Navy [4, p. 176, 5, p. 328]. It is $4.4 \mathrm{~m}$ long, $1.72 \mathrm{~m}$ beam and $0.76 \mathrm{~m}$ deep and was built of four tree species: Quercus robur (English oak), Pinus sylvestris (Forest pine), Ulmus campestris (Elm) and

D. Ashkenazi

dana.ashkenazi@gmail.com; dana@eng.tau.ac.il

1 Department of Maritime Civilizations, University of Haifa, 3498838 Haifa, Israel

2 Materials Laboratory, Israel Electric Corporation, 3508510 Haifa, Israel

3 School of Mechanical Engineering, Tel Aviv University, 6997801, Ramat Aviv, Tel Aviv, Israel

4 Leon Recanati Institute for Maritime Studies, University of Haifa, 3498838 Haifa, Israel
Juglans regia (English walnut). The shell of the boat was built using double diagonal planking, a novel method for vessels at that time [6, p. 218]. The double diagonal planking is based on two layers of planks laid at an angle of about $90^{\circ}$ to each other and connected with nails (see below Nail no. 4). Hence, instead of relying on the frames $(3 \mathrm{~cm}$ sided and $2.5 \mathrm{~cm}$ moulded, with an average room and space of $40 \mathrm{~cm}$ ) for strength, the builder used an internal mould for the construction of the hull. This method overcame a disadvantage of wood, which is a non-homogenous material: its stress strength along its axis being much higher than its stress strength perpendicular to its axis [7, p. 352].

The Spartan anchored off Akko (St. Jean d'Acre) on the Bay of Haifa in the summer of 1847 under the command of Captain Thomas Symonds. Lieutenant Thomas Molyneux, accompanied by three crew members, left the ship for a 3-week expedition through the Sea of Galilee, down the River Jordan and into the Dead Sea. The aim was to study the course of the Jordan Rift Valley and make soundings of the Dead Sea by boat [8, p. 53, 9, p. 104]. The boat and equipment were transported from Akko to the Sea of Galilee by camel. The crew carried out soundings of the Sea of Galilee, found the exit of the River Jordan and followed it southward to the Dead Sea, sailing wherever possible and portering the boat when the river was too shallow [8, p. 54]. 
They returned with the boat overland from the Dead Sea via Jericho and Jerusalem to the Mediterranean, where they boarded the Spartan at anchor off Jaffa. The main results of this expedition were a better understanding of the meandering nature of the River Jordan, which solved many scientific disagreements of the Dead Sea seabed depths and knowledge of its surroundings [2, p. 26, 3, p. 250, 9, p. 113].

Lieutenant Molyneux gave Captain Symonds a detailed journal and a sketch map of his activities, which Symonds arranged to be published as an article in the Journal of the Royal Geographical Society [3, p. 253]. Molyneux died a few days after the end of the expedition, as a result of the severe conditions of the journey. When Symonds retired from naval service, he received the boat and kept it as a souvenir. The boat was used as a roof for a summer bower in the garden of his house in Torquay, south-east England [2, p. 33, 3, p. 257]. The boat and its story were discovered in 1962 by the late Professor Ze'ev Vilnay, an Israeli historian. It was purchased and brought to Israel [3, p. 257] and displayed at the Beit Hayotzer Museum at Neve Zohar, on the shore of the Dead Sea, later being transferred for display at the Dead Sea Works. In 2008, the boat was brought to the Leon Recanati Institute for Maritime Studies at the University of Haifa for preservation and conservation. During this time, the boat was laser-scanned by a Hemispherical 3D
Scanners Surphaser ${ }^{\circledR}$ system, which has a $0.2 \mathrm{~mm}$ accuracy of point measurement and an overall-accumulated accuracy of $1 \mathrm{~mm}$ (Fig. 1). Following the two years of treatment and study of the hull details, it was returned for display at the Dead Sea Works.

\section{Metallurgical Background to Metal Fastenings}

\section{Technological Developments of Steel and Fastenings}

From Antiquity until the nineteenth century, 'steel' was produced by the cementation process of wrought iron, or by the bloomery process $[10$, p. 219,11, p. 105]. The manufacturing technologies of ferrous alloys underwent significant developments during the nineteenth century in order to obtain better quality products [10, p. 219, 12, pp. 108-109]. The technological changes in the nail industry followed the general technological developments and improvements of the steel industry in the course of that period [13, p. 79]. Only during the second half of the nineteenth century were wrought iron, cast iron and steel distinguished according to differences in their carbon content, and the first parts of the

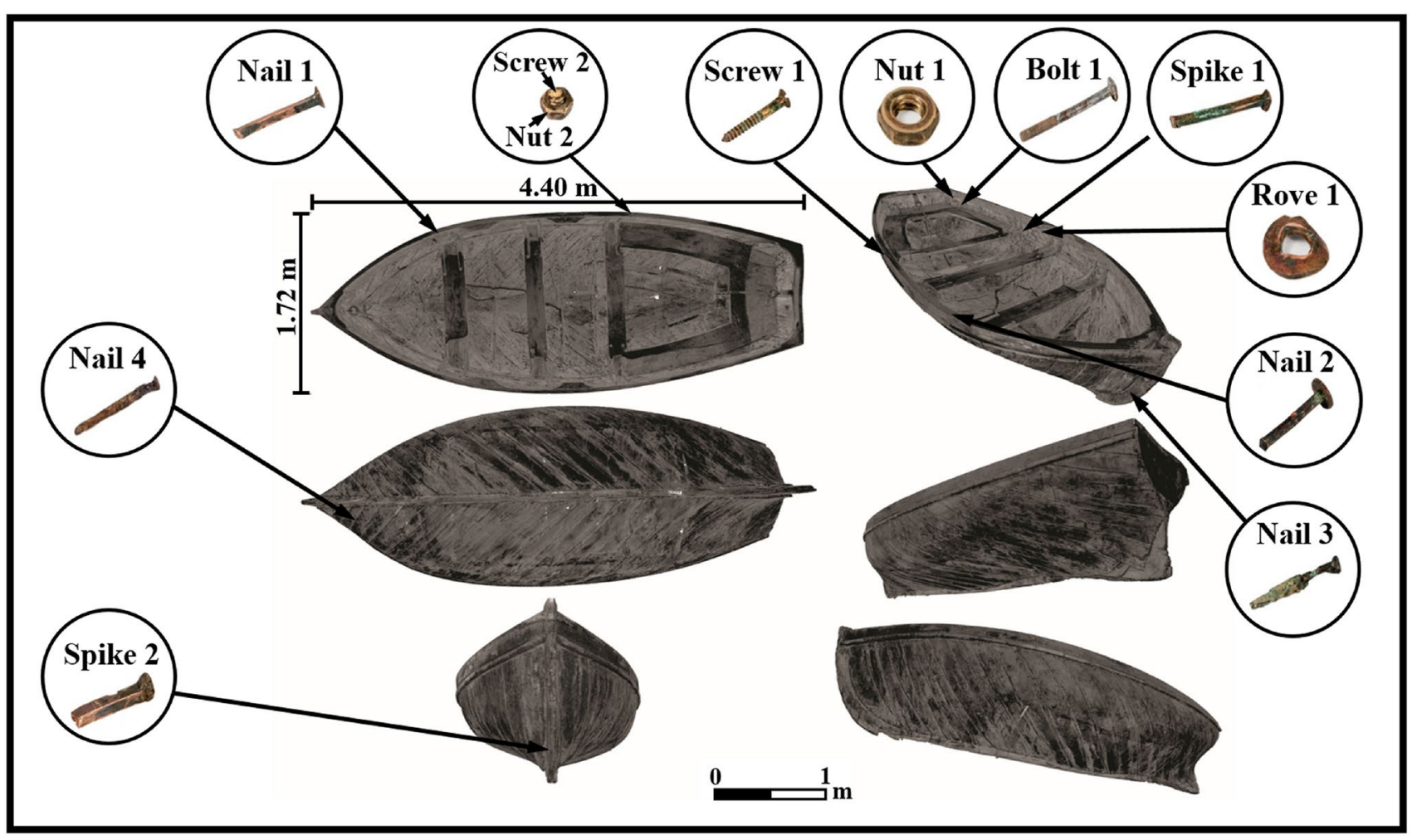

Fig. 1 Laser scan of the Molyneux's boat with fastenings locations (Boat scan: Mabat 3D Technologies; photograph of the fastenings: A. Efremov; adapted by M. Bram) 
iron-carbon (Fe-C) equilibrium phase diagram were published between 1895 and 1899. However, only at the end of the nineteenth century was a significant connection established between the actual physical basis and the industrial production of ferrous alloys, which led to a rapid increase in the volume of production and the quality of the alloys [10, p. 219].

From about 1766 until the second half of the nineteenth century, steel was produced from cast iron in a semi-solid state by the puddling process with charcoal fuel. This led to poorer mechanical properties than wrought iron, due to uncontrolled carbon content, combined with the presence of impurities of $\mathrm{P}, \mathrm{S}, \mathrm{Si}$ and $\mathrm{Mn}$ in the solid solution. The Bessemer process for mass production of steel from pig iron by using an air blast was developed independently by W. Kelly in 1851 and H. Bessemer, who patented it in 1856. The Bessemer process could remove carbon from the metal, but it could not reduce the amount of P and S [10, p. 226, 11, p. 164]. During the second half of the nineteenth century, new methods for chemical analysis were developed and became available for industrial purposes; for example, Kirchhoff-Bunsen spectroscopy in 1859 and the Le Chatelier thermocouple in 1886. The development of such methods for chemical analyses led to better industrial control possibilities and improved product quality [10, p. 227]. In the middle of the 1890s, steel started to replace wrought iron in most applications, including nail production [13, p. 81].

Until the end of the eighteenth century, blacksmiths made ferrous nails from wrought iron nail rods or plates. Red-hot rods were hammered to a point, held in a vice and hammered to create the head, resulting in variations in the dimensions and shape of hand-made nails. Producing forged hand-made nails was a slow and labour-intensive process; however, no particular equipment was required other than a blacksmith's tools, such as a hammer, anvil and header [13, pp. 81-82, 14, p. 67]. Hand-made wrought nails were replaced later in the nineteenth century by machine-cut nails [14, pp. 67, 71]. However, there is some evidence for the use of hand-made ferrous nails for marine applications in the early nineteenth century. For example, hand-made nails were retrieved from the Akko 1 shipwreck, the remains of an Egyptian armed vessel, which was built at the beginning of the nineteenth century. The nails were discovered in a wooden box that was part of the ship's carpenter's tools. Metallurgical analysis of these nails demonstrated a heterogeneous microstructure of ferrite, Widmanstätten ferrite and pearlite, and that they were made by hot-working processes followed by pack carburization surface hardening of 2-3 $\mathrm{mm}$ thick to improve their mechanical surface properties [15, pp. 427, 438].

Since nails were among the most widely used metal objects in the nineteenth century, they serve as important data source, based on documentary sources, typology, composition and manufacturing process $[13$, p. 78,14 , pp.
66-69]. For example, machine cut-and-headed nails, which were superior for building purposes, were introduced in 1815 , and wire nails patented by C. Fremont were available from 1819. Machine-made wire nails were presented at the Paris Exhibitions of 1844 and 1855 and at the Great Exhibition in London in 1851. However, although wire nails had already been produced in the USA since the 1850 s, largescale mass production of wire nails only began in the $1880 \mathrm{~s}$ [14, pp. 66-69, 16, p. 85]. Nails are often used for the determination of terminus ante quem and terminus post quem of archaeological sites. For instance, the existence of modern machine-cut nails in an archaeological site indicates a date in the 1830s or later. The transition from wrought handmade nails to machine-made nails took place in the USA in $1820-1840$ and in Great Britain in 1840-1860. The transition from iron nails to steel nails occurred in the 1880 s, following the large-scale mass production of steel in the late 1870 s with the adaptation of the Bessemer process [13, pp. 80, 87, 14 pp. 66-69].

\section{Galvanized Steel}

In 1836, S. Sorel developed the galvanizing process, where ferrous metal was dipped into a molten zinc bath to create an anti-corrosion coating and patented it a year later [17, p. 82, 18, p. 8]. In 1837 Crawford patented a similar process in England. The development of the galvanizing process boosted the zinc production industry. Sorel established five different galvanizing processes: (1) 'hot dip' coating, where molten zinc alloy was coated on an iron substrate, which was used for building applications; (2) 'galvanic paint' coating, using powdered metallic zinc mixed with oils or varnish; (3) 'galvanic paste', applied as a cream made of metallic zinc particles mixed with oily substances; (4) 'galvanic powder', applied to immersed iron parts, primarily for storage; and (5) 'galvanic paper', a zinc-coated paper used to wrap small iron parts [18, p. 8]. About 1844, an electro-galvanizing process was established, only capable of depositing thin pure zinc coats, which was abandoned before 1861. The first American patent for galvanizing iron was registered in 1868 , and during the last quarter of the nineteenth-century galvanization, galvanizing was already a common process [17, pp. 82-83].

\section{Copper Nails}

During Antiquity copper was used for various applications based on its properties, including good corrosion resistance, reasonable erosion resistance, ductility and the ability to increase hardness and strength by strain hardening [19, p. 124]. Examination of Roman copper nails from southwestern Iberia revealed very pure copper, composed of 99.2-99.9 wt $\% \mathrm{Cu}$, with the presence of up to $0.7 \mathrm{wt} \%$ of $\mathrm{Pb}, \mathrm{Fe}$ and As according to micro-EDXRF analysis, with 
distorted recrystallized grains and some annealing twins, signs of post-casting forging and annealing (thermomechanical processing), whereas the tip of the nails was hardened. Such iron content in Roman copper objects indicates effective smelting operations [20, pp. 117-120]. The Vickers microhardness indentation test results of the copper nails were 56-67 HV at the shank and $112 \mathrm{HV}$ closer to the nail tip [20, pp. 119, 121]. The Romans used lead sheathing secured by copper tacks to protect their ships [21, p. 4].

In 1691, 20 Royal Navy ships were covered with milled lead sheathing to protect them against Teredo navalis. The lead sheathing was fastened with copper tacks, resulting in electrolytic problems [22, p. 219]. About 1708, C. Parry suggested a method for sheathing ships with copper to the Royal Navy [23, p. 23]. The first Royal Navy vessel was sheathed with copper in 1761, and the first US ships were copper-sheathed in 1777 [23, p. 24, 24, p. 259]. Copper has been in extensive use by the Royal Navy since 1780 [21, p. 4]. During the eighteenth century, copper nails were used in naval applications to secure copper plates to the wooden hull, although relatively pure copper fastenings were found to be soft and were replaced by more suitable copper alloy fastenings [23, p. 24,25 , p. 448]. In 1786, the Royal Navy decided to replace the fastenings of all naval ships with copper bolts [23, p. 25]. From the last quarter of the eighteenth century, the demand to protect the hulls of a growing number of Navy vessels required massive quantities of copper sheets and fastenings (nails and bolts). In 1790 all British ships-ofthe-line and many other Navy ships were copper-sheathed to prevent damage to the hull by marine organisms, and all their ferrous fastenings were replaced by copper bolts [22, p. 222]. In order to prevent galvanic corrosion, a similar composition was needed for both sheet and fastenings [26, p. 264]. Copper nails and bolts retrieved from the Rapid (1811) shipwreck were examined by traditional metallographic examination and SEM-EDS analysis. The results revealed that the nails were made of hammered and partially annealed copper, composed of $99.6-99.8 \mathrm{wt} \% \mathrm{Cu}$, with the presence of up to $0.4 \mathrm{wt} \%$ of $\mathrm{Pb}, \mathrm{Fe}$ and $\mathrm{Ni}[19, \mathrm{p} .124]$.

\section{Technological Developments of Brass Alloy Fastenings}

Brass has been used since the Roman period for various applications, including coins, musical instruments, 'golden' helmets, jewellery and ornaments [27-29]. It has a beautiful golden-yellow appearance and advanced properties, such as hardness (it is stronger and harder than copper and can be hardened further by cold working), and excellent corrosion resistance in salt water environments. However, under corrosion attack it tends to suffer dezincification [27, p. 012,018, 28, p. 104306]. Processes such as bending, cold rolling and deep drawing can be easily applied to $\alpha$-brass [27, p. 012018].

Until the beginning of the nineteenth century, $\alpha$-brass alloys were produced by the cementation process, with a zinc content of 20-28 wt \%. In the cementation process, copper, calamine and coal were placed together into a vessel, heated to a temperature above the boiling point of zinc $\left(907^{\circ} \mathrm{C}\right)$, but below the melting point of copper $\left(1083^{\circ} \mathrm{C}\right)$, causing the zinc vapour to diffuse into the copper. The cementation method continued to be the major process for brass production until 1816, when the production of brass from metallic zinc was started. However, calamine furnaces were still operating until 1858 [29, pp. 252-253].

Brass production was expanded during the Industrial Revolution. In 1738, W. Champion patented a process in Britain for the production of zinc through the refinement of zinc from calamine with charcoal in a furnace [27, p. 012018]. Brass with $32.5 \mathrm{wt} \% \mathrm{Zn}$ appeared around 1750 $[29$, p. 253]. Brass alloy with less than $39 \mathrm{wt} \% \mathrm{Zn}$ tends to solidify as a $\alpha$-brass solid solution, and brass with zinc content higher than $39 \mathrm{wt} \% \mathrm{Zn}$ solidifies as a $\alpha+\beta$ alloy. The $\alpha$-phase solid solution has a face-centred cubic (FCC) unit cell, and the $\beta$ phase is the intermetallic non-stoichiometric $\mathrm{Cu} / \mathrm{Zn}$ compound with a body-centred cubic (BCC) unit cell [30, 31, pp. 13-15]. In 1832, Muntz patented a process for the production of $60 / 40$ brass ( $60 \mathrm{wt} \% \mathrm{Cu}$ and $40 \mathrm{wt} \% \mathrm{Zn}$ ). During the 1850s, Muntz metal started to replace copper as the main sheathing metal used in Britain [23, p. 27].

In the course of the nineteenth century, brass was used for many marine applications, including nails [30], cases [32], hook-and-eye closures [33], flintlock musket fittings [34], oil lamp wick housings [35] and rolled sheets [36]. More than a hundred brass nails retrieved from the Akko Tower shipwreck, which was a 25-m-long European merchantman sunk about the middle of the nineteenth century in Akko harbour, were of two types: A (long nails) and B (short nails), distinguished by their general shape and size. All nails were post-cementation products, created by casting. Type A nails contained 35-36 wt\% Zn and had a Widmanstätten lamella microstructure, and Type B nails contained 33-34 wt\% zinc and had $\alpha$-brass grains containing a dendritic microstructure, indicating that they were manufactured differently [30]. Analysis of anisotropy of magnetic susceptibility (AMS) revealed that Type A nails were of better quality than Type $B$ [37]. The lead isotope analysis of the nails suggested that their raw material probably originated in Great Britain [30].

\section{The Metal Fastenings}

Various types of metal fastenings were used in the hull: spikes, nails, bolts, screws, roves and nuts (Figs. 1 and 2). Where possible, a representative example of each type of 


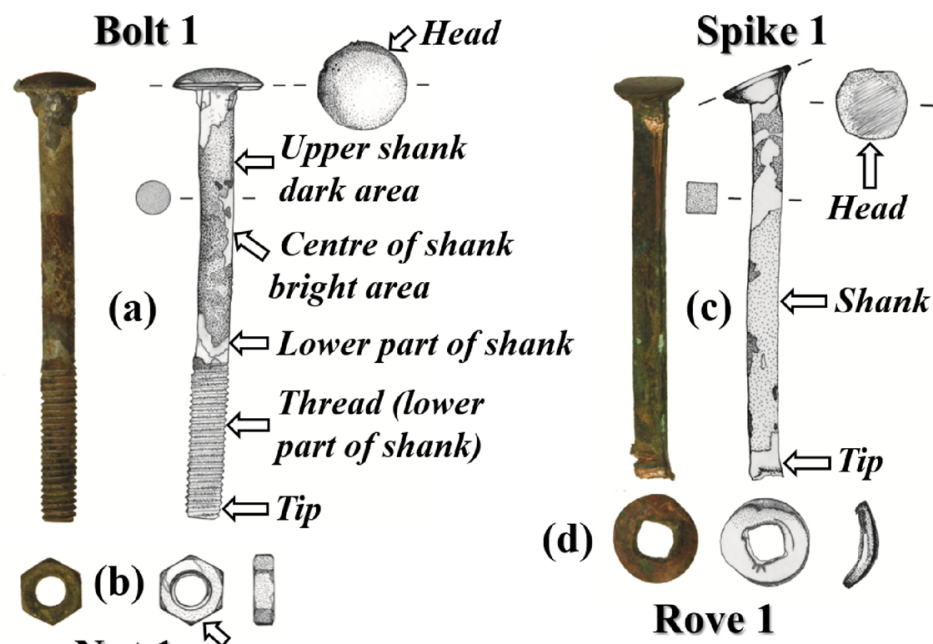

Nut 1 Hexagon (j)

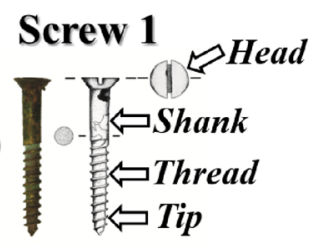

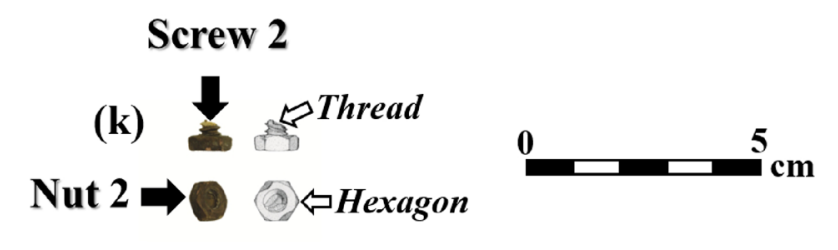

Fig. 2 The metal fastenings (general view and cross sections): a Carriage bolt no. 1 made of galvanized low-carbon steel; $\mathbf{b}$ brass nut no. 1; c copper spike no. 1; $\mathbf{d}$ copper rove no. 1; e copper spike no. 2; f-h

fastenings was sampled for further study. Some of the fastenings were slightly damaged during their removal from the hull. Following is a description of items analysed in this paper:

Bolt no. 1. A carriage bolt [38, p. 185] made of galvanized low-carbon steel used to secure the lodging knee on the port side of the stern. It is $94.7 \mathrm{~mm}$ long, with an average head diameter of $17.7 \mathrm{~mm}$, and weighed $32.4 \mathrm{~g}$. The upper $55.6 \mathrm{~mm}$ part of the bolt is round and $7 \mathrm{~mm}$ in diameter (measured $22 \mathrm{~mm}$ below the head); the lower part of the bolt is $7.8 \mathrm{~mm}$ in diameter (measured $17 \mathrm{~mm}$ from its tip), with a right-hand Whitworth 5/16"-18 thread $31.2 \mathrm{~mm}$ long. The external surface colour is brown with some shades of grey and green. Six bolts of this type are found in the boat used for the same purpose.

Nut no. 1. The hexagon brass nut of bolt no. 1. It is $7.5 \mathrm{~mm}$ thick; the cross section of the outer hexagon is $12.7 \mathrm{~mm} \times 12.8 \mathrm{~mm} \times 13 \mathrm{~mm}$, and its inner diameter is $6.4 \mathrm{~mm}$. The nut weighed $3.2 \mathrm{~g}$.

Spike no. 1. A copper spike used to secure the hanging knee of thwart 1 on the port side. Its lower part was found broken, and its total surviving length is $79.2 \mathrm{~mm}$. Given that the side planking of the hull is $2 \mathrm{~cm}$ thick, the knee is up to $8 \mathrm{~cm}$ moulded, and the copper rove is $0.3 \mathrm{~cm}$ thick-its original length should be about $10 \mathrm{~cm}$. The head size is $14.3 \mathrm{~mm} \times 14.6 \mathrm{~mm}$. The shank cross section is copper nails no. 1, 2 and 3 ; $\mathbf{i}$ ferrous nail no. 4 ; $\mathbf{j}$ brass screw no. 1; and $\mathbf{k}$ brass screw no. 2 and brass nut no. 2 (Photograph: J. J. Gotlieb; drawing: L. Levert)

$6.1 \mathrm{~mm} \times 6.6 \mathrm{~mm}$ below the head and $6.3 \mathrm{~mm} \times 6.4 \mathrm{~mm}$ at the tip. The spike weighed $31 \mathrm{~g}$. It is brown with shades of light green at the surface. There are 12 spikes of this type in the boat used for the same purpose.

Rove no. 1. A copper rove with a typical square hole was most likely used to secure a nail (such as spike no. 1) or a through bolt by clinching (or riveting) the end or point over the wood [38, p. 181, 39, p. 269]. In this boat it was used with spike no. 1 only. The diameter of the ring is $13 \mathrm{~mm}$, and the section of the inner hole is $7.4 \mathrm{~mm} \times 7.8 \mathrm{~mm}$. The ring is $2.8 \mathrm{~mm}$ thick and weighed $4 \mathrm{~g}$. Only a single example of this type was taken from the hull.

Spike no. 2. A copper spike used to fasten the keelson and the rising wood to the keel. It was found broken at its lower tip and has a length of $42.8 \mathrm{~mm}$. Considering that it was driven through the $3-\mathrm{cm}$ moulded rising wood and the $15-\mathrm{cm}$ moulded keel, it seems that its original length is about $10 \mathrm{~cm}$. It has an average head diameter of $13.7 \mathrm{~mm}$, and the square shank cross section is $7.2 \mathrm{~mm} \times 7.2 \mathrm{~mm}$ below the head and $6.4 \mathrm{~mm} \times 6.4 \mathrm{~mm}$ at the broken end. The spike weighed $15.3 \mathrm{~g}$. It is shiny yellow, with shades of light green. Six spikes of this kind are found in the boat for longitudinal wooden structural components.

Nail no. 1. A copper nail used to secure the starboard end of the clamp next to thwart 2. Its lower part is broken, and its total length is $36.8 \mathrm{~mm}$. The nail's original length is about 
$4 \mathrm{~cm}$, considering that the clamp is $2 \mathrm{~cm}$ moulded, and the side of the hull is $2 \mathrm{~cm}$ thick. It has an average head diameter of $7.9 \mathrm{~mm}$. The upper part of the nail is twisted, with a Sect. $3 \mathrm{~mm} \times 3.5 \mathrm{~mm}$ below the head and $3.3 \mathrm{~mm} \times 3.4 \mathrm{~mm}$ at the broken end. The nail weighed $3.2 \mathrm{~g}$. It is shiny yellow with a few patches of light green. About 20 nails of this type found in the boat used for the same purpose.

Nail no. 2. A copper nail used to fasten a strake to starboard frame 6 . Its lower part is broken, and it has a total length of $32.8 \mathrm{~mm}$. Considering that it was driven through the $2-\mathrm{cm}$-thick planking and the $2.5-\mathrm{cm}$ moulded frame, its original length was about $4 \mathrm{~cm}$. The average head diameter is $11 \mathrm{~mm}$, and the shank's square section is $3.8 \mathrm{~mm} \times 3.9 \mathrm{~mm}$ below the head and $3.7 \mathrm{~mm} \times 3.8 \mathrm{~mm}$ at the broken end. It weighed $4.7 \mathrm{~g}$. The nail has a dark colour with small spots of light green. Eighteen nails of this type are found in the boat used for the same purpose.

Nail no. 3. A copper nail used to fasten external strake 2 to the rising wood and the starboard side of the keelson. Its lower part is broken, and it has a total surviving length of $37.9 \mathrm{~mm}$, with an average head diameter of $7.1 \mathrm{~mm}$. The upper part of the nail is twisted, with a square section of $1.8 \mathrm{~mm} \times 1.9 \mathrm{~mm}, 8 \mathrm{~mm}$ below the head and $2.5 \mathrm{~mm} \times 2.7 \mathrm{~mm}$ at the broken end. The nail weighed $2.5 \mathrm{~g}$. The colour is dark with some light green patches, and it is covered with concretion. Eight nails of this type are found in the boat used for the same purpose.

Nail no. 4. A ferrous nail used to fasten the two layers of strakes at the starboard side of the bow. It was found broken at its lower end and has a total surviving length of $29.2 \mathrm{~mm}$, with an average head diameter of $3.8 \mathrm{~mm}$. The upper part of the nail is twisted, with the shank diameter of $2.4 \mathrm{~mm}$ below the head and $2.4 \mathrm{~mm}$ at the broken end. It weighed $0.6 \mathrm{~g}$. The nail has a dark colour, and it is also concreted.
There are about 200 nails of this kind in the boat used for the same purpose.

Screw no. 1. A brass screw used to secure the plate of the aft starboard oarlock (there are two lines of oars in the boat with total four oarlocks positions). It is $34 \mathrm{~mm}$ long, with an average head diameter of $8 \mathrm{~mm}$. The upper $11 \mathrm{~mm}$ of the shank is round and $4 \mathrm{~mm}$ in diameter (measured $3 \mathrm{~mm}$ below the head, at the centre of the round part); the lower $20.3 \mathrm{~mm}$ of the screw had a right-hand thread, and the shank is $3.1 \mathrm{~mm}$ (measured $10 \mathrm{~mm}$ from the tip, at the centre of the thread). The screw has a $1.1 \mathrm{~mm}$ width slot countersunk head. It weighed $3 \mathrm{~g}$. The colour is shiny yellow with patches of light green. There are 16 screws of this type in the boat used for the same purpose.

Screw no. 2. The lower end of a brass screw used to fasten the starboard gunwale above thwart 2. It is $6 \mathrm{~mm}$ long. The average head diameter was not available. The shank is $4.4 \mathrm{~mm}$ in diameter, with a right-hand thread. A complete screw weighed $1.4 \mathrm{~g}$. There are about 68 screws of this type in the boat used for the same purpose.

Nut no. 2. A hexagon brass nut connected to screw no. 2. The dimension of the outer hexagon is $8 \mathrm{~mm} \times 8.2 \mathrm{~mm} \times 8.4 \mathrm{~mm}$, and the nut is $3.8 \mathrm{~mm}$ thick.

\section{Experimental Methods}

The fastenings were studied by various methods (Table 1), as described below:

(a) Visual testing (VT) was carried out on all items to examine their state of preservation and to detect macroscopic level details, such as discontinuities and defects indicative of their manufacturing process.

Table 1 Description of the metal fastenings from Molyneux's boat and their characterization method

\begin{tabular}{|c|c|c|c|c|c|c|c|}
\hline \multirow[t]{2}{*}{ Artefact } & \multirow[t]{2}{*}{ Material } & \multicolumn{6}{|l|}{ Characterization method } \\
\hline & & $\begin{array}{l}\text { VT, dimensions and } \\
\text { weight measurements }\end{array}$ & XRF & Multifocal LM & Metallography & Vickers microhardness & SEM-EDS \\
\hline Bolt no. 1 & Galvanized steel & + & + & + & + & + & + \\
\hline Nut no. 1 & Brass & + & + & + & + & + & + \\
\hline Nail no. 4 & Iron & + & + & + & + & + & + \\
\hline Spike no. 1 & Copper & + & + & + & + & + & + \\
\hline Spike no. 2 & Copper & + & + & + & + & + & + \\
\hline Rove no. 1 & Copper & + & + & + & + & + & + \\
\hline Nail no. 1 & Copper & + & + & + & + & - & + \\
\hline Nail no. 2 & Copper & + & + & + & + & + & + \\
\hline Nail no. 3 & Copper & + & + & + & + & + & + \\
\hline Screws 1 & Brass & + & + & + & + & + & + \\
\hline Screws 2 & Brass & + & + & + & + & + & + \\
\hline Nut no. 2 & Brass & + & - & + & + & + & + \\
\hline
\end{tabular}


(b) Dimensions and weight measurements of all items were taken using a digital calliper and an analytical balance with precision scale of $0.0001 \mathrm{~g}$.

(c) A thread gauge was used on bolt no. 1 to determine the pitch.

(d) X-ray fluorescence (XRF) chemical analysis was carried out with a handheld XRF (HH-XRF) instrument, using silicon drift detector and LE operation mode, equipped with a $45 \mathrm{kV}$ Rh target $\mathrm{x}$-ray tube. Each measurement was made in a bench-top stand for $30 \mathrm{~s}$, with a detected area of $5 \mathrm{~mm}$ in diameter. The HHXRF instrument was calibrated with standard calibration samples. HH-XRF instruments measure common alloy elements to within an accuracy of less than $0.5 \%$ of the measured value. However, since HH-XRF is a surface analysis, the external surface of the fastenings may not be representative of their bulk composition, due to the thick corrosion layers, and the presence of carbonates, oxides, chlorides, sulphides and/or sulphates [40, p. 1903]. Therefore, the surface of each item was roughly ground with $80-320$ grit papers to expose the original metal, cleaned with ethanol and dried before examination. This instrument has some limitations; for example, it cannot focus on small spots with a diameter of less than a few millimetres. For a representative result, the emitted photons should be absorbed in the first $10-100 \mu \mathrm{m}$ of the detected surface, depending on the $\mathrm{x}$-ray beam energy, the surface roughness and the material density. When using $\mathrm{HH}-\mathrm{XRF}$ technology, it is challenging to distinguish between the peaks of $\mathrm{Pb}$ and As due to low level peak overlap, especially when strong peaks are present. Therefore, the HH-XRF measurements were made by comparing two independent peaks: the As $\mathrm{K} \alpha$ peak was compared with the $\mathrm{Pb} \mathrm{M} \alpha$ peak; and the As $\mathrm{K} \beta$ peak was compared with the $\mathrm{Pb} \mathrm{L} \beta$ peak. Moreover, light elements, such as carbon and oxygen, could not be detected with this XRF machine, due to instrumental limitations.

(e) A multifocal 3D digital light microscope (LM) with high intensity LED lighting and an improved light sensitivity sensor at high resolution HD $(1920 \times 1200)$, displaying high pixel density and low image noise, with an auto-focus and multi-focus system was used to detect microscopic level discontinuities and defects, as well as to examine the general conservation of the surface [41]. This instrument contains powerful software and encoded optics designed for the avoidance of human errors by automatically using the correct lens.

(f) For metallographic examinations, the samples were cut into longitudinal (L-CS) and transverse (T-CS) sections according to ASTM E3-11 (2011) Standard and were mounted in Bakelite. The surface was roughly ground with 80 grit paper and then with 600-4000 silicon carbide grit papers, polished with $1 \mu \mathrm{m}$ aluminium oxide polishing suspension and then with $0.04 \mu \mathrm{m}$ colloidal silica suspension. After each step contaminants were removed in an ultrasonic bath. The specimens were then cleaned with ethanol, dried and etched. The steel samples were etched with Nital (97\% alcohol and $3 \% \mathrm{HNO}_{3}$ ), and the copper and brass samples were etched with hydrochloric acid in ferric chloride solution $\left(\mathrm{FeCl}_{3}-\mathrm{HCl}-\mathrm{H}_{2} \mathrm{O}\right)$. The microstructure of the metallographic samples was examined with an Olympus BX60M optical light microscope (LM), equipped with a DeltaPix Invenio 3SII camera.

(g) (g) Vickers microindentation hardness (HV) measurements were made on the metallographic samples, with $200 \mathrm{gf}$ load, and $15 \mathrm{~s}$ dwell time for indents, according to ASTM E 384-99 standard.

(h) (h) Chemical composition mapping and localized chemical analyses were made using a scanning electron microscope (SEM) with energy-dispersive spectroscopy (EDS) in order to determine both the microstructure and composition. The instrument was equipped with a silicon drift detector (Brucker XFlash 4010), with EDS resolution of $129 \mathrm{eV}$, and was calibrated with standard samples, providing measurements with an approximate error of $0.1-1 \%$ [42].

\section{Results}

\section{Bolt and Nut}

Based on the VT observation, bolt no. 1 (Fig. 2) is well preserved. It has a bright silver-grey appearance, but in some areas an orange brown corroded surface is exposed, indicating that it is made of iron (Fig. 3a-b). The upper and central part of the shank was smooth, and about $40 \%$ of the bolt length is threaded. The thread of the shank at the lower part of the bolt shows corrosion products (Fig. 3a). The uniform helical ridge at the lower part of the bolt indicated that it was produced by an industrial process. The shiny metallic coating at the smooth part of the bolt suggests that it was galvanized to protect it against corrosion (Fig. 3b). However, the dark areas, where the zinc coating was eroded away, showed corrosion evidence (Fig. 3b, dark areas).

$\mathrm{XRF}$ analysis of the bolt's dark external surface (before it was ground, Fig. 3b, right side of image) revealed a composition of $97.7 \mathrm{wt} \% \mathrm{Fe}$. However, the presence of up to $1 \mathrm{wt} \%$ of $\mathrm{Al}, \mathrm{Si}, \mathrm{S}, \mathrm{Mn}, \mathrm{Ni}, \mathrm{Cu}$ and $\mathrm{Pb}$ was also detected (Table 2). XRF analysis of the bolt's bulk (ground metal) also showed it is mostly composed of iron $(98.3 \mathrm{wt} \% \mathrm{Fe})$; however, the presence of up to $0.5 \mathrm{wt} \%$ of $\mathrm{Al}, \mathrm{Si}, \mathrm{S}, \mathrm{Mn}, \mathrm{Ni}$ and $\mathrm{Cu}$ was also detected (Table 2). XRF analysis of the bolt's bright 

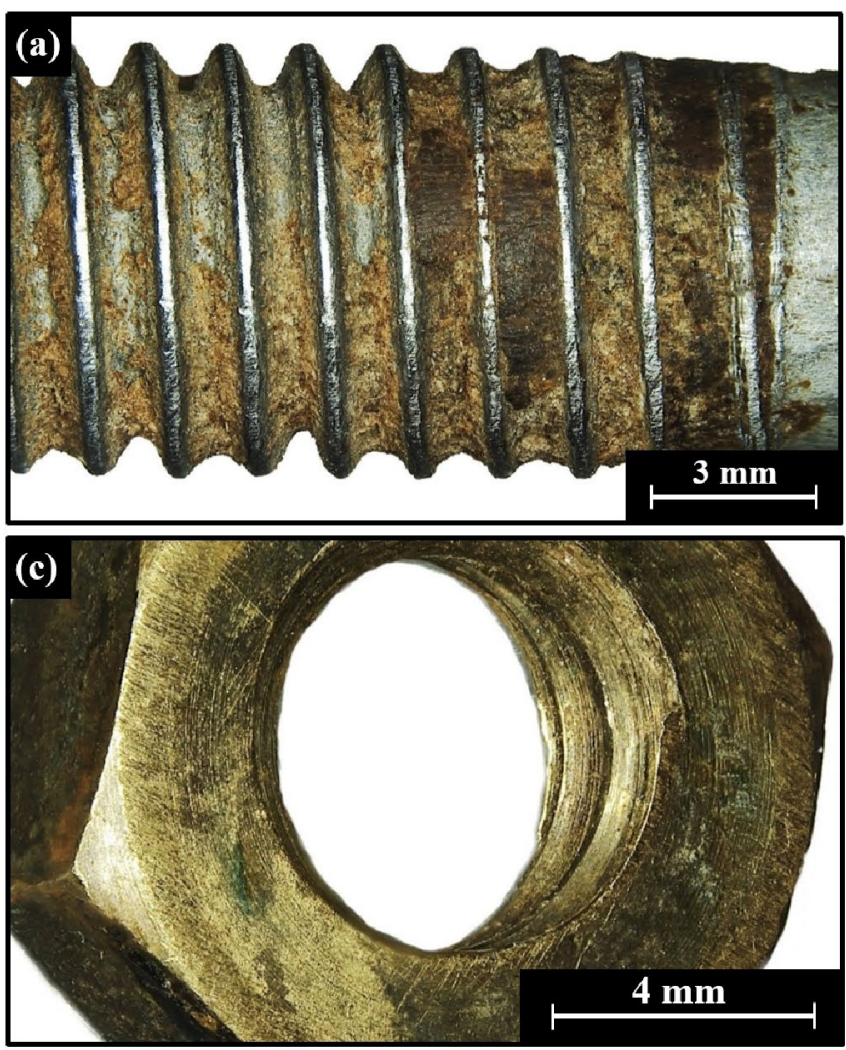

Fig. 3 Multifocal LM images of galvanized low-carbon steel bolt no. 1 and brass nut no. 1: a the shank's thread; $\mathbf{b}$ the bolt's shank coated with zinc (bright area) and areas of exposed iron with corrosion prod-

external surface (Fig. 3b, central part of image) revealed it is composed of 46.7-69.9 wt\% $\mathrm{Zn}, 27.9-50.2 \mathrm{wt} \% \mathrm{Fe}$, up to $2.5 \mathrm{wt} \% \mathrm{Si}$, up to $1.1 \mathrm{wt} \% \mathrm{Cu}$ and up to $0.3 \mathrm{wt} \%$ of $\mathrm{S}, \mathrm{Ni}, \mathrm{Cu}$, $\mathrm{Pb}$ and $\mathrm{Sn}$, indicating that the bolt was made of galvanized steel (Table 2). The high concentrations of Si are possibly due to migration of sediment during the long period of erosion and galvanic corrosion process [43, p. 522, 44, pp. 381, 384]. SEM-EDS analysis revealed that the bolt's metal bulk was composed of 97.7-98.5 wt\% Fe, 0.1-0.3 wt\% $\mathrm{Si}$, as well as less than $1 \mathrm{wt} \%$ of $\mathrm{Mn}, \mathrm{Mo}, \mathrm{Cr}$ and $\mathrm{Ni}$ (Table 3).

LM observation of the bolt revealed that it was made of low-carbon steel (0.1-0.2 wt\% C), and it exhibited a microstructure of equiaxed ferrite grains with pearlite islands and some inclusions (Fig. 4a). The ferrite grain size is 5-30 $\mu \mathrm{m}$ (Fig. 4a). Dark parallel elongated manganese sulphide (MnS) inclusions surrounded by an iron matrix were observed at the shank by SEM (Fig. 4b), evidence of plastic deformation. SEM-EDS analysis of a typical inclusion (Fig. 4b, arrow) revealed that it was composed of $57.1 \mathrm{wt} \% \mathrm{Mn}, 30.0 \mathrm{wt} \%$ $\mathrm{S}, 11.7 \mathrm{wt} \% \mathrm{Fe}$ and up to $0.7 \mathrm{wt} \%$ of $\mathrm{O}, \mathrm{Cr}, \mathrm{Si}$ and $\mathrm{Cu}$. The presence of such entrapped inclusions can affect the mechanical properties of the steel, and hence, they should be removed as far as possible in the steelmaking process.
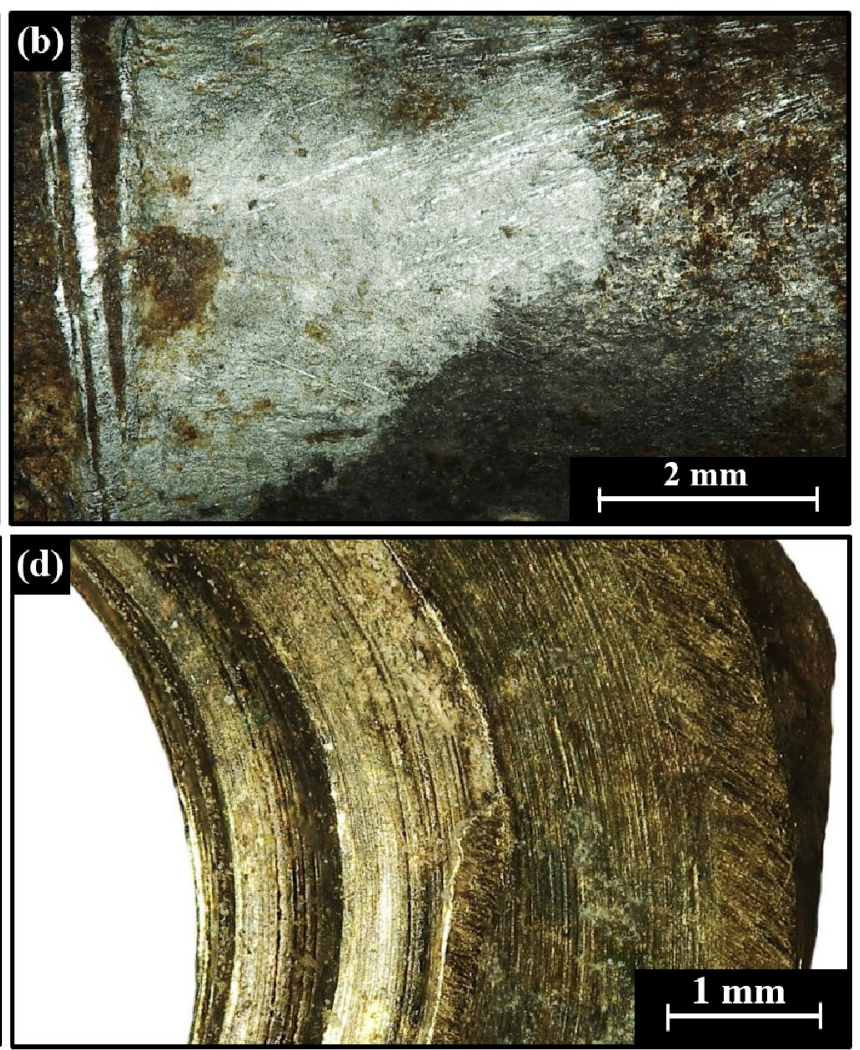

ucts (dark areas); $\mathbf{c}$ the brass nut; and $\mathbf{d}$ higher magnification of the nut showing machining marks

The microhardness of the bolt samples varied between $162 \mathrm{HV}$ at the shank and $231 \mathrm{HV}$ close to the thread, with average microhardness of $192 \pm 31 \mathrm{HV}$ (Table 4). The microhardness results of the shank are as expected from 0.1 to 0.2 wt $\% \mathrm{C}$ low-carbon steel. For comparison, the microhardness value for modern low-carbon steel is $130 \mathrm{HV}$ [45, p. 455]. The higher microhardness values at the thread of bolt no. 1 is most likely related to an intensive strain hardening (plastic deformation) during the manufacturing process. Microstructure observation of the shank thread shows deformed grains, a feature probably resulting from a thread-rolling process (Fig. 4c, d). The EDS analysis of the bulk of the bolt (centre of shank) revealed that it was composed of iron (97.7 wt\% $\mathrm{Fe}$ ), with the presence of up to $1 \mathrm{wt} \%$ of $\mathrm{Si}, \mathrm{Cr}, \mathrm{Mn}, \mathrm{Ni}$ and Mo. SEM-EDS elemental mapping of the surface (threaded shank, Fig. 5) revealed the zinc coating, which served as sacrificial anode.

The nut of bolt no. 1 (nut no. 1) shows on its surface a well-preserved shiny yellow metal (Fig. 3c), and the observation with higher magnification revealed machining marks (Fig. 3d). LM and SEM images of the metallographic L-CS of this nut revealed elongated and preferentially oriented microstructure (Fig. 6), typical of a cast item shaped by a 
Table 2 XRF chemical analysis of the iron, copper and brass fastenings (local measurements before and after grinding of the surface)

\begin{tabular}{|c|c|c|c|c|c|c|}
\hline \multirow[t]{2}{*}{ Measured area } & \multicolumn{6}{|c|}{ Composition (wt\%) } \\
\hline & $\mathrm{Fe}$ & $\mathrm{Cu}$ & $\mathrm{Zn}$ & $\mathrm{Si}$ & $\mathrm{Pb}$ & Other elements \\
\hline Bolt no. 1, head, dark area, not ground & 97.8 & 0.2 & - & 1.0 & 0.1 & $0.3 \mathrm{Al}, 0.3 \mathrm{~S}, 0.3 \mathrm{Mn}$ \\
\hline Bolt no. 1, head, ground metal & 98.4 & 0.2 & - & 0.4 & - & $0.5 \mathrm{Al}, 0.3 \mathrm{Mn}, 0.2 \mathrm{~S}$ \\
\hline Bolt no. 1, upper shank, bright area, not ground & 37.1 & 0.1 & 59.9 & 2.5 & 0.1 & $0.2 \mathrm{~S}, 0.1 \mathrm{Ni}$ \\
\hline Bolt no. 1, centre of shank (bright area), not ground & 39.6 & 0.1 & 58.2 & 1.7 & 0.1 & $0.2 \mathrm{Sn}, 0.1 \mathrm{Mn}$ \\
\hline Bolt no. 1, shank's thread, bright area, not ground & 27.9 & 0.1 & 69.0 & 2.3 & 0.1 & $0.3 \mathrm{~S}, 0.3 \mathrm{Sn}$ \\
\hline Bolt no. 1, tip, bright area, not ground & 50.2 & 1.1 & 46.7 & 1.5 & 0.3 & $0.2 \mathrm{Sn}$ \\
\hline Nut no. 1 , shiny yellow metal, not ground & 0.4 & 59.2 & 36.8 & 1.4 & 1.2 & $0.7 \mathrm{Sn}, 0.3 \mathrm{Ni}$ \\
\hline Nut no. 1 , ground metal & 0.5 & 59.1 & 37.5 & 0.7 & 1.2 & $0.7 \mathrm{Sn}, 0.3 \mathrm{Ni}$ \\
\hline Nail no. 4 , head, corroded area, not ground & 94.6 & 2.7 & - & 0.1 & 2.0 & $0.3 \mathrm{Mn}, 0.1 \mathrm{~S}$ \\
\hline Nail no. 4 , shank, corroded area, not ground & 52.7 & 6.8 & 3.1 & 25.9 & 11.4 & $0.1 \mathrm{~S}$ \\
\hline Nail no. 4 , tip, corroded area, not ground & 86.8 & 7.0 & - & 1.2 & 4.3 & $1.2 \mathrm{~S}, 0.3 \mathrm{Al}, 0.2 \mathrm{Mn}$ \\
\hline Nail no. 4 , head, ground metal & 97.8 & 1.3 & - & 0.1 & 0.3 & $0.3 \mathrm{Mn}, 0.1 \mathrm{~S}, 0.1 \mathrm{Al}$ \\
\hline Nail no. 4 , shank, ground metal & 91.2 & 3.7 & - & 1.9 & 2.2 & $1.9 \mathrm{~S}, 0.6 \mathrm{Al}, 0.2 \mathrm{Mn}$ \\
\hline Nail no. 4, tip, ground metal & 94.4 & 3.6 & - & 0.4 & 1.0 & $0.4 \mathrm{~S}, 0.3 \mathrm{Mn}, 0.1 \mathrm{Al}$ \\
\hline Spike no. 1 , head, not ground & 0.1 & 98.5 & 0.1 & 1.0 & - & $0.3 \mathrm{As}$ \\
\hline Spike no. 1 , shank, not ground & 0.1 & 97.0 & 0.2 & 1.1 & 0.9 & $0.7 \mathrm{As}$ \\
\hline Spike no. 1 , tip, not ground & 0.1 & 97.3 & 0.2 & 1.1 & 0.9 & $0.4 \mathrm{As}$ \\
\hline Spike no. 1 , head, ground metal & 0.1 & 98.8 & 0.1 & 0.7 & - & $0.3 \mathrm{As}$ \\
\hline Spike no. 1 , shank, ground metal & 0.1 & 98.5 & 0.1 & 0.4 & 0.5 & 0.3 As, 0.1 An \\
\hline Spike no. 1, tip, ground metal & 0.1 & 97.4 & 0.2 & 0.9 & 1.0 & $0.4 \mathrm{As}$ \\
\hline Rove no. 1, ground, area 1 (left side, Fig. 2) & 0.1 & 98.5 & 0.1 & 0.7 & 0.4 & $0.1 \mathrm{Bi}$ \\
\hline Rove no. 1, ground, area 2 (right side, Fig. 2) & 0.1 & 98.7 & 0.1 & 0.7 & - & $0.2 \mathrm{As}, 0.1 \mathrm{Sn}$ \\
\hline Spike no. 2 , head, area of dark oxide, not ground & 1.0 & 68.0 & 0.3 & 22.8 & 6.6 & $1.2 \mathrm{As}$ \\
\hline Spike no. 2, shank, not ground & 4.9 & 93.3 & 0.7 & - & - & $0.8 \mathrm{As}, 0.1 \mathrm{Bi}$ \\
\hline Spike no. 2, tip, not ground & 0.1 & 98.5 & 0.1 & 0.5 & - & $0.5 \mathrm{As}, 0.2 \mathrm{Bi}, 0.1 \mathrm{Sb}$ \\
\hline Spike no. 2 , head, ground metal & 0.1 & 96.8 & 0.1 & 2.2 & 0.3 & $0.4 \mathrm{As}, 0.1 \mathrm{Bi}$ \\
\hline Spike no. 2 , shank, ground metal & 0.1 & 97.2 & 0.1 & 1.8 & - & $0.5 \mathrm{As}, 0.2 \mathrm{Bi}, 0.1 \mathrm{Sb}$ \\
\hline Spike no. 2, tip, ground metal & 0.1 & 98.1 & 0.1 & 1.0 & - & $0.4 \mathrm{As}, 0.2 \mathrm{Bi}, 0.1 \mathrm{Ag}$ \\
\hline Nail no. 1 , head, not ground & 0.1 & 97.1 & 0.1 & 1.5 & 0.9 & $0.2 \mathrm{As}, 0.1 \mathrm{Sb}$ \\
\hline Nail no. 1 , shank, not ground & 0.1 & 96.3 & 0.1 & 2.6 & 0.7 & $0.2 \mathrm{As}, 0.2 \mathrm{Ag}$ \\
\hline Nail no. 1, tip, not ground & 0.1 & 97.9 & 0.1 & 1.1 & 0.8 & - \\
\hline Nail no. 1, head, ground metal & 0.1 & 98.6 & 0.1 & 0.8 & 0.4 & - \\
\hline Nail no. 1 , shank, ground metal & 0.1 & 99.0 & 0.1 & 0.3 & 0.5 & - \\
\hline Nail no. 1, tip, ground metal & 0.1 & 98.7 & 0.1 & 0.6 & 0.5 & - \\
\hline Nail no. 2, head, not ground & 0.4 & 87.8 & 0.5 & 5.0 & 5.4 & $0.8 \mathrm{As}, 0.1 \mathrm{Ag}$ \\
\hline Nail no. 2 , shank, not ground & 0.1 & 97.6 & 0.1 & 1.9 & - & $0.3 \mathrm{As}$ \\
\hline Nail no. 2, tip, not ground & 0.1 & 97.0 & 0.1 & 1.4 & 0.8 & $0.4 \mathrm{As}, 0.1 \mathrm{Bi}, 0.1 \mathrm{Ag}$ \\
\hline Nail no. 2, head, ground metal & 0.2 & 96.5 & 0.2 & 1.1 & 1.3 & $0.5 \mathrm{As}, 0.1 \mathrm{Bi}, 0.1 \mathrm{Ag}$ \\
\hline Nail no. 2 , shank, ground metal & 0.1 & 98.6 & 0.1 & 0.6 & - & $0.4 \mathrm{As}, 0.1 \mathrm{Bi}, 0.1 \mathrm{Ag}$ \\
\hline Nail no. 2, tip, ground metal & 0.1 & 98.9 & 0.1 & 0.3 & - & $0.4 \mathrm{As}, 0.1 \mathrm{Bi}, 0.1 \mathrm{Ag}$ \\
\hline Nail no. 3, head, not ground & 0.1 & 98.1 & 0.2 & 0.5 & 0.7 & $0.3 \mathrm{As}, 0.1 \mathrm{Ag}$ \\
\hline Nail no. 3, shank, not ground & 0.4 & 92.7 & 0.3 & 1.6 & 4.7 & $0.2 \mathrm{Sn}, 0.1 \mathrm{Bi}$ \\
\hline Nail no. 3, tip, not ground & 1.5 & 80.9 & 0.3 & 13.0 & 3.4 & $0.9 \mathrm{As}$ \\
\hline Nail no. 3 , head, ground metal & 0.1 & 98.5 & 0.1 & 0.5 & 0.4 & $0.2 \mathrm{As}, 0.1 \mathrm{Bi}, 0.1 \mathrm{Ag}$ \\
\hline Nail no. 3, tip, ground metal & 0.7 & 98.1 & 0.2 & - & 0.6 & $0.4 \mathrm{As}$ \\
\hline Screw no. 1 , head, not ground & 0.6 & 61.9 & 33.0 & 3.5 & 0.7 & $0.2 \mathrm{As}, 0.1 \mathrm{Sn}$ \\
\hline Screw no. 1 , shank, not ground & - & 66.9 & 32.4 & 0.7 & - & - \\
\hline Screw no. 1 , tip, not ground & 0.1 & 66.2 & 31.3 & 2.3 & 0.1 & - \\
\hline Screw no. 1 , head, ground metal & 0.2 & 66.2 & 29.7 & 3.7 & 0.2 & - \\
\hline
\end{tabular}


Table 2 (continued)

\begin{tabular}{llllllll}
\hline Measured area & \multicolumn{1}{l}{ Composition (wt\%) } \\
\cline { 2 - 8 } & $\mathrm{Fe}$ & $\mathrm{Cu}$ & $\mathrm{Zn}$ & $\mathrm{Si}$ & $\mathrm{Pb}$ & Other elements \\
\hline Screw no. 1, shank, ground metal & 0.1 & 63.8 & 34.2 & 1.8 & 0.1 & - \\
Screw no. 1, tip, ground metal & 0.1 & 64.2 & 31.3 & 4.1 & 0.1 & $0.2 \mathrm{~S}$ \\
Screw no. 2, head, not ground & 0.2 & 63.1 & 33.2 & 2.4 & 1.0 & $0.1 \mathrm{Sn}$ \\
Screw no. 2, tip, not ground & 0.1 & 60.0 & 39.5 & - & 0.4 & - \\
Screw no. 2, head, ground metal & 0.1 & 59.3 & 36.7 & 1.7 & 1.8 & $0.3 \mathrm{~S}, 0.1 \mathrm{Sn}$ \\
Screw no. 2, tip, ground metal & 0.1 & 65.8 & 32.1 & 0.9 & 1.0 & $0.1 \mathrm{Sn}$ \\
\hline
\end{tabular}

Table 3 SEM-EDS chemical analysis of the iron, copper and brass fastenings after they were polished (S.A. is the scanned area)

\begin{tabular}{|c|c|c|c|c|c|c|}
\hline \multirow[t]{2}{*}{ Measured area } & \multicolumn{6}{|c|}{ Composition (wt $\%$ ) } \\
\hline & $\mathrm{Fe}$ & $\mathrm{Cu}$ & $\mathrm{Zn}$ & $\mathrm{Si}$ & $\mathrm{Pb}$ & Other elements \\
\hline Bolt no. 1 , shank, S.A. 1: $150 \mu \mathrm{m} \times 150 \mu \mathrm{m}$ & 97.7 & - & - & 0.3 & - & $\begin{array}{l}0.9 \mathrm{Mn}, 0.8 \mathrm{Cr} \\
0.2 \mathrm{Mo}, 0.1 \mathrm{Ni}\end{array}$ \\
\hline Bolt no. 1 , shank, S.A. 2: $100 \mu \mathrm{m} \times 100 \mu \mathrm{m}$ & 98.5 & - & - & 0.1 & - & $0.8 \mathrm{Mn}, 0.3 \mathrm{Cr}, 0.3 \mathrm{Mo}$ \\
\hline Nut no. 1 , S.A. 1: $100 \mu \mathrm{m} \times 100 \mu \mathrm{m}$ & 0.4 & 60.2 & 38.1 & - & 0.2 & $0.8 \mathrm{Sn}, 0.3 \mathrm{Ni}$ \\
\hline Nut no. 1 , S.A. $2: 100 \mu \mathrm{m} \times 100 \mu \mathrm{m}$ & 0.3 & 60.1 & 38.3 & - & 0.2 & $0.7 \mathrm{Sn}, 0.4 \mathrm{Ni}$ \\
\hline Nut no. 1, S.A. 3: $100 \mu \mathrm{m} \times 100 \mu \mathrm{m}$ & 0.3 & 60.4 & 38.1 & - & 0.2 & $0.7 \mathrm{Sn}, 0.3 \mathrm{Ni}$ \\
\hline Nail no. 4 , shank, S.A. 1: $50 \mu \mathrm{m} \times 50 \mu \mathrm{m}$ & 99.5 & - & - & 0.1 & - & $0.3 \mathrm{Mn}, 0.1 \mathrm{P}$ \\
\hline Nail no. 4 , shank, S.A. $2: 50 \mu \mathrm{m} \times 50 \mu \mathrm{m}$ & 99.7 & - & - & - & - & $0.3 \mathrm{Mn}$ \\
\hline Nail no. 4 , shank, S.A. $3: 50 \mu \mathrm{m} \times 50 \mu \mathrm{m}$ & 99.6 & - & - & 0.1 & - & $0.3 \mathrm{Mn}$ \\
\hline Nail no. 4 , shank, S.A. $4: 50 \mu \mathrm{m} \times 50 \mu \mathrm{m}$ & 99.6 & - & - & 0.1 & - & $0.3 \mathrm{Mn}$ \\
\hline Spike no. 1 , shank, S.A. 1: $100 \mu \mathrm{m} \times 100 \mu \mathrm{m}$ & - & 98.6 & - & 0.1 & 0.3 & $0.7 \mathrm{O}, 0.3 \mathrm{Mg}$ \\
\hline Spike no. 1 , shank, S.A. $2: 100 \mu \mathrm{m} \times 100 \mu \mathrm{m}$ & - & 98.7 & - & - & 0.3 & $0.7 \mathrm{O}, 0.3 \mathrm{Mg}$ \\
\hline Spike no. 1 , shank, S.A. 3: $100 \mu \mathrm{m} \times 100 \mu \mathrm{m}$ & - & 98.3 & - & - & 0.6 & $0.8 \mathrm{O}, 0.3 \mathrm{Mg}$ \\
\hline Spike no. 2 , shank, S.A. 1: $100 \mu \mathrm{m} \times 100 \mu \mathrm{m}$ & - & 96.8 & - & 0.4 & - & $2.0 \mathrm{O}, 0.4 \mathrm{Ni}, 0.2 \mathrm{As}, 0.2 \mathrm{Bi}$ \\
\hline Spike no. 2 , shank, S.A. $2: 20 \mu \mathrm{m} \times 20 \mu \mathrm{m}$ & - & 98.3 & - & 0.3 & - & $0.8 \mathrm{As}, 0.4 \mathrm{Ni}, 0.2 \mathrm{Bi}$ \\
\hline Spike no. 2 , inclusion 1 , S.A.: $5 \mu \mathrm{m} \times 5 \mu \mathrm{m}$ & - & 61.7 & - & 1.4 & 10.7 & 9.5 As, 9.4 Bi, 7.0 O, 0.3 Ni \\
\hline Spike no. 2 , inclusion 2 , S.A.: $5 \mu \mathrm{m} \times 5 \mu \mathrm{m}$ & - & 17.9 & - & 0.7 & 18.1 & $\begin{array}{l}27.4 \mathrm{Bi}, 20.6 \mathrm{As}, \\
14.3 \mathrm{O}, 0.7 \mathrm{Sb}, 0.3 \mathrm{Ni}\end{array}$ \\
\hline Nail no. 1 , shank, S.A.: $50 \mu \mathrm{m} \times 50 \mu \mathrm{m}$ & - & 98.4 & - & 0.2 & 0.1 & $0.2 \mathrm{Ge}, 0.1 \mathrm{Sb}$ \\
\hline Nail no. 2 , shank, S.A 1.: $150 \mu \mathrm{m} \times 150 \mu \mathrm{m}$ & - & 98.6 & - & 0.2 & 0.1 & $0.5 \mathrm{Au}, 0.4 \mathrm{O}, 0.2 \mathrm{Mg}$ \\
\hline Nail no. 2 , shank, S.A 2.: $150 \mu \mathrm{m} \times 150 \mu \mathrm{m}$ & - & 97.2 & - & - & 0.1 & $\begin{array}{l}1.5 \mathrm{~W}, 0.6 \mathrm{O}, 0.3 \mathrm{Ni}, \\
0.3 \mathrm{As}\end{array}$ \\
\hline Nail no. 2 , shank, S.A. $3: 50 \mu \mathrm{m} \times 30 \mu \mathrm{m}$ & - & 99.1 & - & 0.2 & - & $0.3 \mathrm{Au}, 0.3 \mathrm{O}, 0.1 \mathrm{As}$ \\
\hline Nail no. 2 , shank, S.A. $4: 20 \mu \mathrm{m} \times 20 \mu \mathrm{m}$ & - & 97.4 & - & - & 0.2 & $1.5 \mathrm{~W}, 0.4 \mathrm{O}, 0.3 \mathrm{Ni}, 0.2 \mathrm{As}$ \\
\hline Nail no. 2 , inclusion 1 , S.A.: $5 \mu \mathrm{m} \times 5 \mu \mathrm{m}$ & 0.1 & 13.8 & - & - & 32.4 & $\begin{array}{l}20.8 \mathrm{Bi}, 16.3 \mathrm{As} \\
13.4 \mathrm{O}, 3.2 \mathrm{Sb}\end{array}$ \\
\hline Nail no. 2 , inclusion 2 , S.A.: $5 \mu \mathrm{m} \times 5 \mu \mathrm{m}$ & - & 28.0 & - & - & 44.4 & 17.0 As, $10.4 \mathrm{O}, 0.2 \mathrm{Sb}$ \\
\hline Nail no. 3 , S.A.: $80 \mu \mathrm{m} \times 80 \mu \mathrm{m}$ & - & 97.6 & - & 0.2 & - & $1.4 \mathrm{~W}, 0.4 \mathrm{O}, 0.3 \mathrm{Ni}, 0.1 \mathrm{As}$ \\
\hline Nail no. 3 , inclusion, S.A.: $5 \mu \mathrm{m} \times 5 \mu \mathrm{m}$ & - & 13.5 & - & 0.1 & 30.4 & $\begin{array}{l}27.8 \mathrm{Bi}, 14.4 \mathrm{O} \\
12.8 \mathrm{As}, 0.6 \mathrm{~F}, 0.2 \mathrm{Sb}, 0.2 \mathrm{Ni}\end{array}$ \\
\hline Rove no. 1, S.A.1: $200 \mu \mathrm{m} \times 200 \mu \mathrm{m}$ & - & 97.0 & - & 0.8 & - & $1.7 \mathrm{O}, 0.4 \mathrm{Ni}, 0.1 \mathrm{As}$ \\
\hline Rove no. 1 , S.A. $2: 200 \mu \mathrm{m} \times 200 \mu \mathrm{m}$ & - & 96.8 & - & 0.6 & 0.3 & $1.8 \mathrm{O}, 0.3 \mathrm{Ni}, 0.2 \mathrm{As}$ \\
\hline Rove no. 1, S.A. 3: $200 \mu \mathrm{m} \times 200 \mu \mathrm{m}$ & - & 97.0 & - & 0.5 & 0.2 & $1.8 \mathrm{O}, 0.3 \mathrm{Ni}, 0.1 \mathrm{As}, 0.1 \mathrm{Bi}$ \\
\hline Rove no. 1 , inclusion, S.A.: $5 \mu \mathrm{m} \times 5 \mu \mathrm{m}$ & - & 30.8 & - & - & 25.2 & $\begin{array}{l}18.9 \mathrm{Bi}, 11.1 \mathrm{As}, \\
9.8 \mathrm{O}, 3.4 \mathrm{Sb}, 0.8 \mathrm{Ni}\end{array}$ \\
\hline Screw no. 1 , shank, S.A. 1: $500 \mu \mathrm{m} \times 500 \mu \mathrm{m}$ & - & 62.3 & 37.7 & - & - & - \\
\hline Screw no. 1 , shank, S.A. 2: $500 \mu \mathrm{m} \times 500 \mu \mathrm{m}$ & - & 62.9 & 37.1 & - & - & - \\
\hline Screw no. 1 , shank, S.A. 3: $500 \mu \mathrm{m} \times 500 \mu \mathrm{m}$ & - & 58.0 & 40.3 & - & 1.7 & - \\
\hline
\end{tabular}



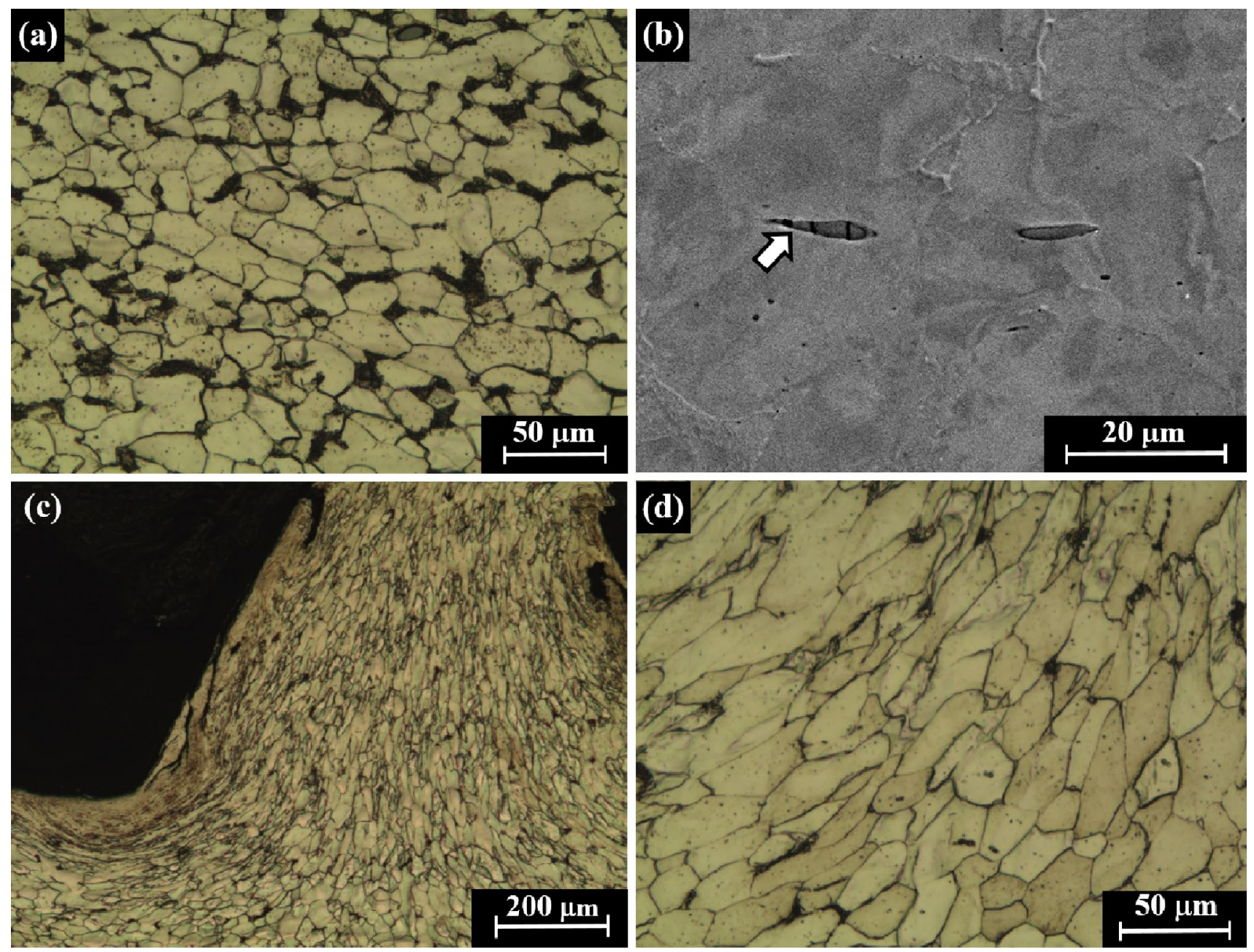

Fig. 4 Metallographic images of galvanized low-carbon steel bolt no. 1's shank: a equiaxed ferrite grains with pearlite islands (L-CS, etched, LM); b two elongated MnS inclusions (dark areas, where the left inclusion is marked with a white arrow), surrounded by ferrite

subsequent thermomechanical work. Based on the machining marks at the threaded hole (internal thread), the manufacturing process was probably combined with a thread cutting machining process (Fig. $3 \mathrm{c}-\mathrm{d}$ ). XRF analysis revealed that the nut was made of brass, composed of 59.1-59.2 wt $\%$ $\mathrm{Cu}, 36.8-37.5 \mathrm{wt} \% \mathrm{Zn}, 1.2 \mathrm{wt} \% \mathrm{~Pb}$, with minor contents of $\mathrm{Sn}, \mathrm{Si}, \mathrm{Fe}$ and Ni (Table 2). SEM-EDS analysis revealed that the nut's metal bulk was composed of 60.1-60.4 wt $\%$ $\mathrm{Cu}, 38.1-38.3 \mathrm{wt} \% \mathrm{Zn}$, and the presence of less than $1 \mathrm{wt} \%$ of $\mathrm{Fe}, \mathrm{Pb}, \mathrm{Sn}, \mathrm{Ni}$ (Table 3). The microhardness of nut no. 1 varied between 156 and $170 \mathrm{HV}$, with an average value of $163 \pm 5$ HV (Table 4).

\section{Ferrous Nail}

Based on the VT observation, nail no. 4 is severely corroded. Multifocal LM observation of the external surface of the matrix (L-CS, before etching, SEM); $\mathbf{c}$ the shank's thread showing deformed grains (T-CS, etched, LM); and $\mathbf{d}$ higher LM magnification of the deformed grains

nail revealed light brown orange and dark brown corrosion products (Fig. 7a, b), typical of iron oxide generated by the redox reaction between iron and oxygen. The XRF analysis of the corroded external layer of the nail before grinding indicated a composition of 52.7-94.6 $\mathrm{wt} \% \mathrm{Fe}$, up to 3.1 wt\% $\mathrm{Zn}$, up to $25.9 \mathrm{wt} \% \mathrm{Si}, 2.7-7.0 \mathrm{wt} \% \mathrm{Cu}, 2.0-11.4 \mathrm{wt} \%$ $\mathrm{Pb}$, up to $0.1-1.2 \mathrm{wt} \% \mathrm{~S}$ and up to $0.3 \mathrm{wt} \%$ of $\mathrm{Al}$ and $\mathrm{Mn}$ (Table 2). The high Si content (25.9 wt\% Si) in one of the corroded area measurements is most probably due to migration of sediment from the surroundings [43, pp. 381, 384, 44 , p. 522]. The XRF analysis of the ground nail indicated a composition of 91.2-97.8 wt\% Fe, 1.3-3.7 wt\% Cu, 0.1-2.2 wt $\% \mathrm{Si}, 0.3-2.2 \mathrm{wt} \% \mathrm{~Pb}, 0.3-1.9 \mathrm{wt} \% \mathrm{~S}$ and up to $0.6 \mathrm{wt} \%$ of $\mathrm{Al}$ and $\mathrm{Mn}$. The high $\mathrm{Pb}$ and $\mathrm{Cu}$ content is unusual for an iron nail [15, pp. 432, 434]; thus, it is possibly related to the long period of corrosion [44, p. 522]. An iron nail produced by the Bessemer process was expected to show the presence 
Table $4 \mathrm{HV}$ microhardness test of the metal fastenings (metallographic samples)

\begin{tabular}{|c|c|c|c|c|}
\hline \multirow[t]{2}{*}{ Sample } & \multicolumn{4}{|c|}{ Vickers microhardness (HV) } \\
\hline & Minimum & Maximum & Average & SD \\
\hline Bolt no. 1 (steel, centre of shank, Fig. 2) & 148 & 164 & 159 & 9 \\
\hline Bolt no. 1 (steel, lower part of the shank, area 1, thread, Fig. 3a) & 205 & 265 & 236 & 5 \\
\hline Bolt no. 1 (steel, lower part of the shank, area 2, above thread, Fig. 3b) & 182 & 202 & 189 & 9 \\
\hline Nut no. 1 (brass, area 1, left side of the nut in Fig. 2) & 165 & 170 & 163 & 5 \\
\hline Nut no. 1 (brass, area 2, right side of the nut in Fig. 2) & 144 & 155 & 148 & 5 \\
\hline Nail no. 4 (steel, shank) & 301 & 322 & 316 & 9 \\
\hline Spike no. 1 (copper, shank) & 138 & 155 & 146 & 7 \\
\hline Spike no. 2 (copper, head) & 131 & 139 & 135 & 4 \\
\hline Spike no. 2 (copper, shank) & 103 & 106 & 104 & 1 \\
\hline Rove no. 1 (copper) & 84 & 106 & 94 & 8 \\
\hline Nail no. 2 (copper, head) & 131 & 143 & 137 & 5 \\
\hline Nail no. 2 (copper, shank) & 104 & 115 & 111 & 5 \\
\hline Nail no. 3 (copper, head) & 138 & 143 & 142 & 2 \\
\hline Nail no. 3 (copper, shank) & 99 & 104 & 101 & 2 \\
\hline Screw no. 1 (brass, head) & 168 & 171 & 170 & 2 \\
\hline Screw no. 1 (brass, shank) & 142 & 146 & 145 & 2 \\
\hline Screw no. 2 (brass) & 145 & 154 & 150 & 3 \\
\hline Nut no. 2 (brass) & 172 & 181 & 177 & 3 \\
\hline
\end{tabular}

of phosphorus [10, p. 226, 11, p. 164]; however, no P was detected by the XRF analysis. This result may be explained due to the poor state of preservation of the corroded nail and instrumental limitations of the XRF.

LM observation of the metallographic sample of the nail revealed that it was made of steel (Fig. 7c): however, the carbon content could not be measured because of the poor preservation condition. The SEM-EDS analysis of the nail (centre of shank) revealed that it was composed of iron (99.1-99.5 wt\% Fe), with the presence of up to $0.3 \mathrm{wt} \%$ of Si, Mn, P and O (Table 3). The microhardness of the nail's bulk varied between 301 and $322 \mathrm{HV}$, with an average value of $316 \pm 9 \mathrm{HV}$ (Table 4), typical of annealed hypereutectoid steel microstructure, based on the presence of pearlite, which strengthens the steel [46, p. 88, 47, p. 130]. However, cold deformation may have also been a possible reason for such microhardness values [48, p. 82].

According to the EDS analysis, no $\mathrm{S}$ was detected (although it was observed by the XRF analysis), and $\mathrm{P}$ was detected only in one measurement (Table 3 ). This result may be explained by heterogeneity of the nail combined with small scanned areas, as well as instrumental limitations of the EDS, and the poor preservation of the nail.

\section{Copper Fastenings}

The six copper fastenings (spikes no. 1-2, nails $1-3$ and rove no. 1, Figs. 1 and 2) were well preserved, with some exposed shiny orange metallic areas (Fig. 8). Areas of green, turquoise, brown and black minerals were observed on the surface of spikes nos. 1 and 2 (Fig. 8). Areas of exposed shiny metal, as well as green, turquoise, yellow, brown and black minerals, were also observed on the surface of nails no. 1-3 (Fig. 8). The XRF analysis of the copper spikes, nails and rove (ground metal) revealed that they were composed of 96.5-99.0 wt\% Cu, with the presence of $\mathrm{Zn}, \mathrm{Si}$, $\mathrm{Fe}, \mathrm{Pb}, \mathrm{Sn}, \mathrm{As}, \mathrm{Bi}, \mathrm{Sb}$ and $\mathrm{Ag}$ (Table 2); however, no $\mathrm{S}$ was detected.

LM observation of the metallographic sample of the head and upper shank of spike no. 1 revealed slip bands and some deformation twins (Fig. 9a). The average microhardness of spike no. 1 varied between $139 \mathrm{HV}$ at the shank and $152 \mathrm{HV}$ at the head, with an average value of 146 7 HV (Table 4), as expected from copper fastenings produced at the end of the 18th-early nineteenth century by the traditional manufacturing process of hammering alternating with annealing cycles [49, pp. 73-75, 50, p. 93]. LM and SEM observations of the central part of spike no. 1's shank revealed equiaxed grains, with a grain size of 10-50 $\mu \mathrm{m}$ (Fig. 9b-d), with some annealing twins and the presence of slag inclusions (1-10 $\mu \mathrm{m})$, as typical of nineteenth-century smelted and annealed copper [51, p. 370]. The SEM-EDS analysis of the bulk of spike no. 1's shank revealed that it was made of copper alloy, composed of 98.3-98.7 wt\% $\mathrm{Cu}$, with the presence of up to $0.8 \mathrm{wt} \%$ of $\mathrm{Si}, \mathrm{Pb}, \mathrm{Mg}$ and $\mathrm{O}$ (Table 3).

The microhardness of spike no. 2's bulk varied between 103 and $139 \mathrm{HV}$, with an average value of $104 \pm 1 \mathrm{HV}$ for the head and $135 \pm 4 \mathrm{HV}$ for the shank (Table 4). SEM-EDS 

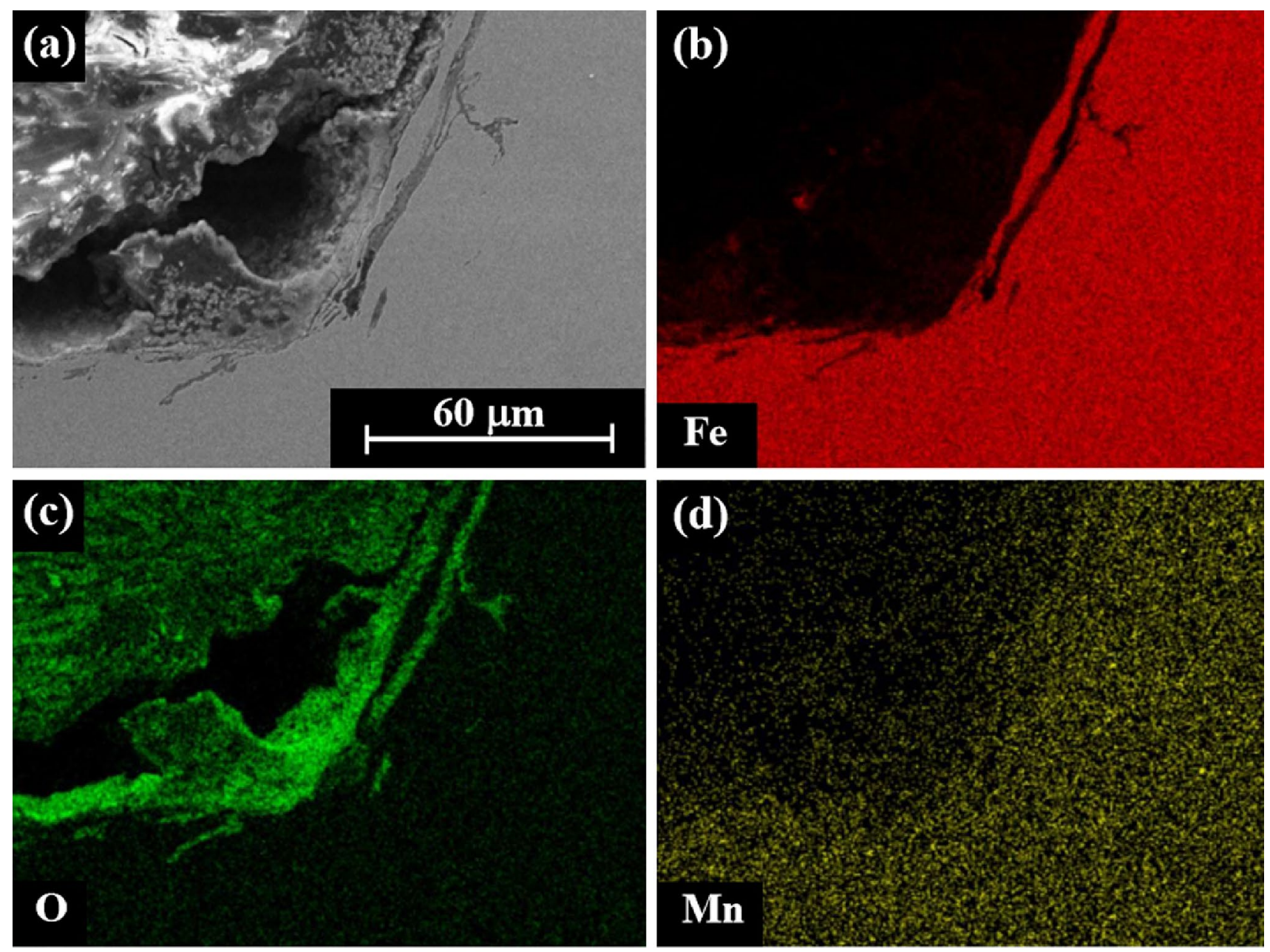

(e)

(f)

\section{Zn}

\section{$\mathrm{Cu}$}

Fig. 5 SEM-EDS elemental mapping of bolt no. 1 (metallographic sample before etching, bright dots): $\mathbf{a}$ the surface of the bolt at the area of the shank; and $\mathbf{b}-\mathbf{f}$ the presence of the elements: iron, oxygen, manganese, zinc and copper

analysis of the inclusions of spike no. 2 revealed a composition of 17.9-61.7 wt\% Cu, 10.7-18.1 wt\% Pb, 9.5-20.6 wt\% As, 9.4-27.4 Bi, 7.0-14.3 wt\% O, as well as up to 1.4 of $\mathrm{Si}$, $\mathrm{Sb}$ and Ni (Table 3 ).
LM and SEM observation of rove no. 1 revealed elongated grains with some annealing twins and the presence of elongated slag inclusions at the planar cross section, as typical to plastically deformed grains that were partially 

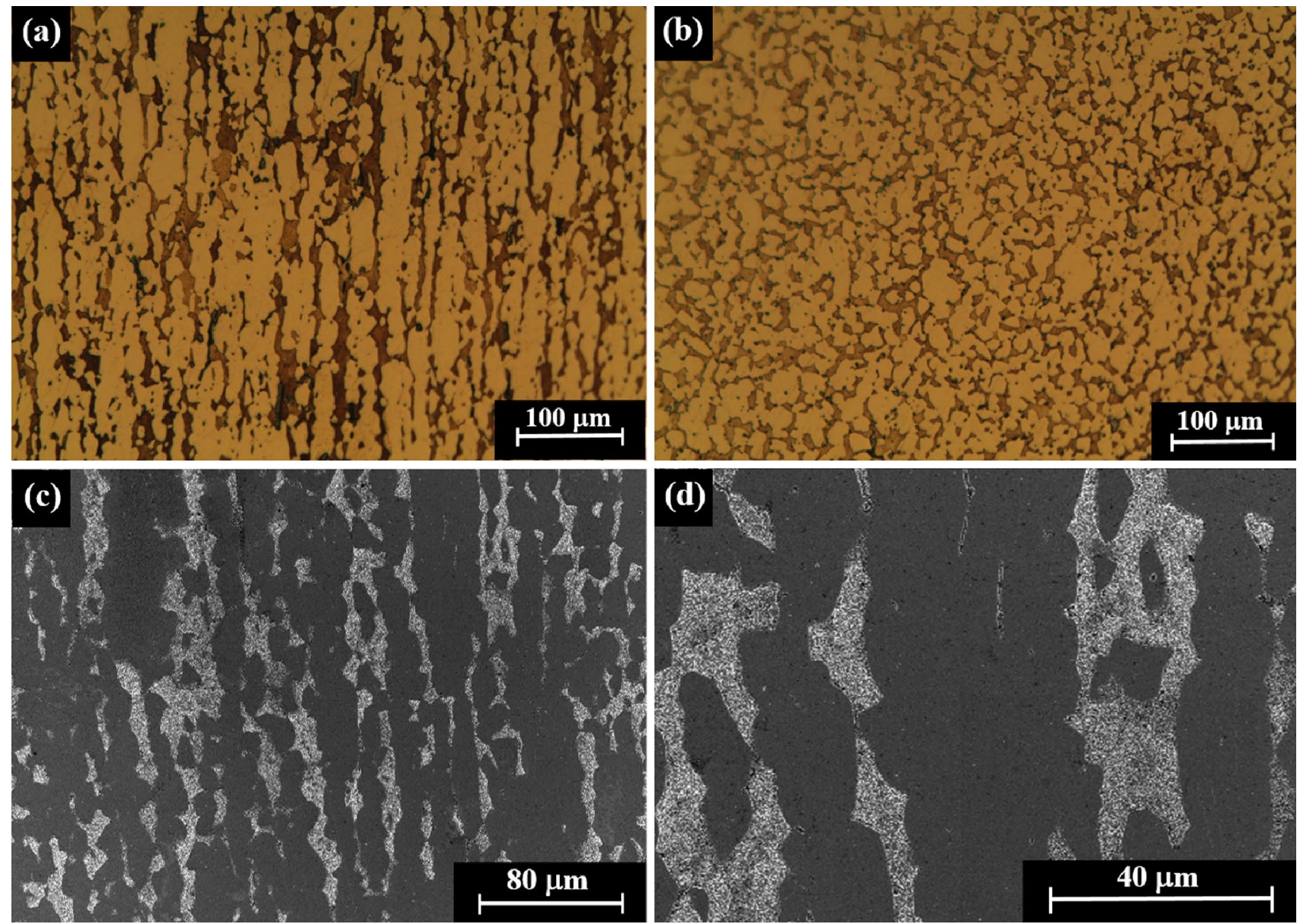

Fig. 6 Metallographic images of brass nut no. 1 (after etching): a LM (L-CS); b LM (T-CS); $\mathbf{c}$ and d SEM (L-CS)

annealed [52, p. 84]. The microhardness of rove no. 1 varied between 84 and $106 \mathrm{HV}$, with an average value of $94 \pm 8$ HV (Table 4). The SEM-EDS analysis of the bulk of rove no. 1 revealed it was made of copper alloy of 96.8-97.0 wt \% $\mathrm{Cu}$, with the presence of up to $1.8 \mathrm{wt} \%$ of $\mathrm{Si}, \mathrm{Pb}, \mathrm{O}, \mathrm{Ni}, \mathrm{As}$ and $\mathrm{Bi}$ (Table 3).

LM and SEM observations of the central part of nails nos. $1-3$ revealed equiaxed grains with a grain size of $10-40 \mu \mathrm{m}$, with some annealing twins and the presence of slag inclusions $(1-10 \mu \mathrm{m})$ (Fig. 10), as typical of annealed copper [51, p. 370]. Some of the inclusions were arranged in parallel strings (Fig. 10a), as also observed by others [53, pp. $76,85]$. The microhardness of the bulk of nail no. 2 varied between 104 and $143 \mathrm{HV}$, with an average value of $137 \pm 5$ HV for its head and $111 \pm 5$ HV for its shank. The microhardness of the bulk of nail no. 3 varied between 99 and $143 \mathrm{HV}$, with an average value of $142 \pm 2 \mathrm{HV}$ for its head and $101 \pm 2 \mathrm{HV}$ for its shank. The SEM-EDS analysis of the bulk of nails nos. 1-3 indicated that they were made of copper alloy of 97.2-99.1 wt\% $\mathrm{Cu}$, with the presence of up to 1.5 wt $\%$ of $\mathrm{Si}, \mathrm{Pb}, \mathrm{O}, \mathrm{W}, \mathrm{As}, \mathrm{Sb}, \mathrm{Au}, \mathrm{Ni}, \mathrm{Mg}$ and
Ge (Table 3). EDS analysis of the inclusions of nails nos. 2 and 3 (white arrows, Fig. 10d, f, respectively) revealed a composition of $13.5-28.0 \mathrm{wt} \% \mathrm{Cu}, 30.4-44.4 \mathrm{wt} \% \mathrm{~Pb}$, up to $27.8 \mathrm{wt} \% \mathrm{Bi}, 12.8-17.0 \mathrm{wt} \% \mathrm{As}, 10.4-14.4 \mathrm{wt} \%$ O, up to 3.2 wt $\% \mathrm{Sb}$ and up to 0.6 of $\mathrm{Si}, \mathrm{Fe}$ and Ni (Table 3).

\section{Brass Screws and Nut}

Areas of green and turquoise minerals were observed on the surface of both screws (Fig. 11a-c, screw no. 1). Screw no. 1 was well preserved (Fig. 11a-c), with a shiny metallic yellow colour; and the metal of screw no. 2, although broken, is also well preserved (Fig. 11d-f). Observation of the metallographic samples of screw no. 1 head, shank and tip revealed equiaxed grains with the presence of twins and deformation lines (LM, Fig. 12a-c). The brass grain size is $5-40 \mu \mathrm{m}$ (Fig. 12c). Observation of screw no. 2 nut revealed a preferentially oriented dendritic microstructure (Fig. 12d-f), which indicated that this item was made first by casting [24, p. 261, 54, p. 4839], following thermomechanical work. Based on the machining marks at the nut's threaded hole, 

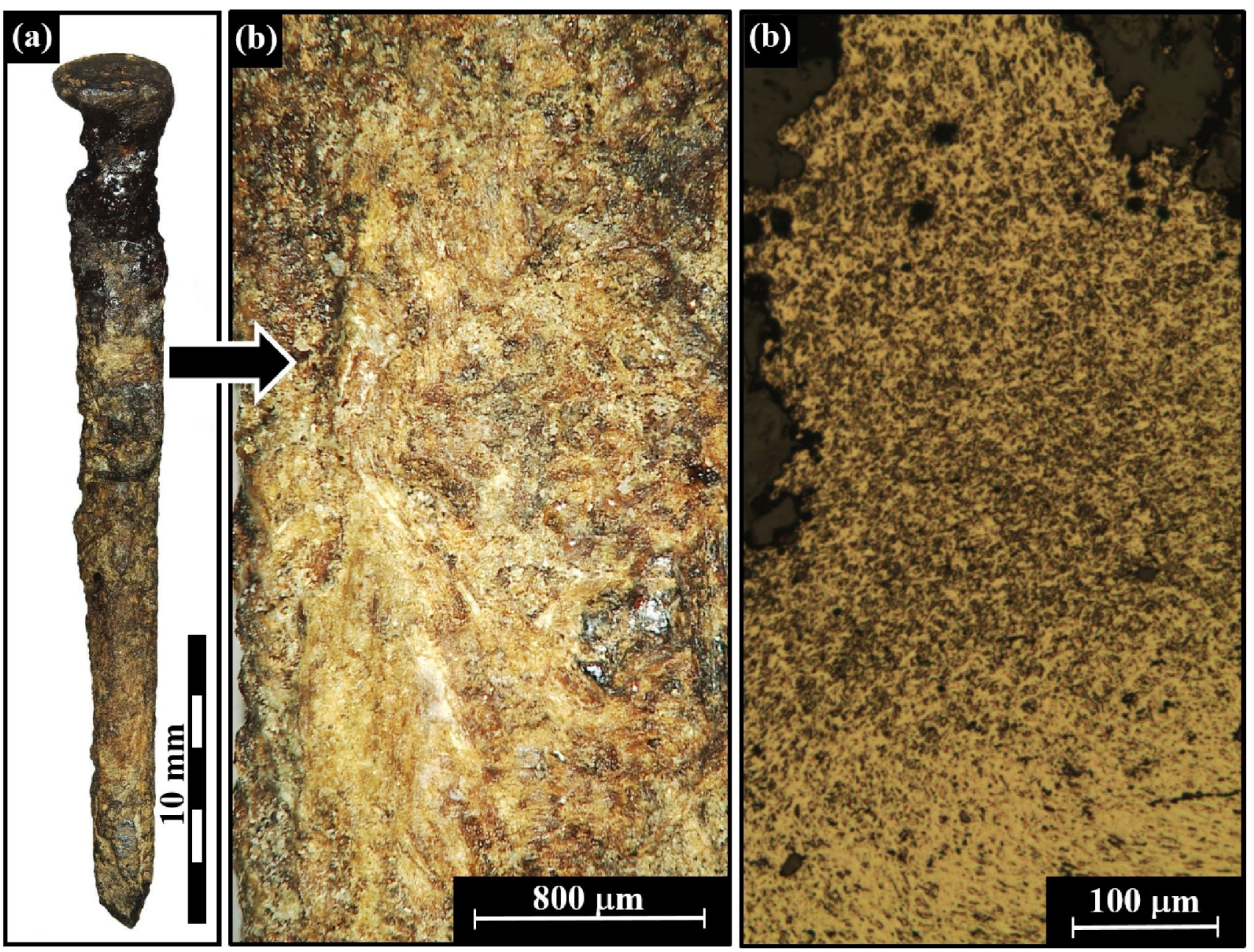

Fig. 7 Multifocal LM images of steel nail no. 4: a general view of the corroded iron nail; $\mathbf{b}$ the external surface of the nail's shank, covered with orange brown rust; and $\mathbf{c}$ metallographic image of the etched nail

the manufacturing process was probably combined with a thread cutting machining process (Fig. 12f).

Based on the XRF analysis, the screws were made of alpha-beta brass, composed of 59.6-66.9 wt\% $\mathrm{Cu}$ and 29.7-39.5 wt\% Zn, with the presence of $\mathrm{Si}, \mathrm{S}, \mathrm{Fe}, \mathrm{Pb}, \mathrm{Sn}$ and As (Table 2). The source of Si could have resulted from the presence of inclusions in the brass, or remains of sand casting [30, p. 296]. SEM-EDS analysis of screw nos. 1 and 2 indicated a composition of $62.3-62.9 \mathrm{wt} \% \mathrm{Cu}$ and 37.1-37.7 wt\% Zn (Table 3). SEM-EDS analysis of nut no. 2 revealed a composition of $58.0 \mathrm{wt} \% \mathrm{Cu}, 40.3 \mathrm{wt} \% \mathrm{Zn}$ and 1.7 $\mathrm{wt} \% \mathrm{~Pb}$. The composition of the screws is within the range of the $60 / 40 \mathrm{Cu} / \mathrm{Zn}$ alpha-beta brass patented by Muntz in 1832 (Patent no. 6347) [30, p. 192], while the $\mathrm{Pb}$ content found in the nut points out to a material that was produced after 1846 [29, 30, p. 201, 55]. Based on the yellow colour of the screws and their composition, no evidence of dezincification was observed. The average microhardness of screw no. 1 metallographic sample varied between $166 \mathrm{HV}$ at the shank and $238 \mathrm{HV}$ at the head, with an average value of $201 \pm 37$ HV (Table 4); and the microhardness of screw no. 2 varied between 148 and $154 \mathrm{HV}$, with an average value of $150 \pm 3 \mathrm{HV}$. For comparison, the hardness of brass cases retrieved from the nineteenth-century Akko 1 shipwreck, produced from rolled sheets that were annealed and then hand-formed with simple tools, was 99-207 HV for grain size of 50-100 $\mu \mathrm{m}[32$, p. 2415]. The average hardness of $\alpha$-brass housing, made of hot-worked rolled sheet, retrieved from the Dor $\mathrm{C}$ shipwreck dated to the last quarter of the nineteenth century, varied between $126 \mathrm{HV}$ and 173 for average grain size of $46 \mu \mathrm{m}$ [35, p. 439].

\section{Discussion}

Investigation of fastenings found in ancient, post-medieval and historic (eighteenth and nineteenth centuries) shipwrecks may provide useful information regarding different 

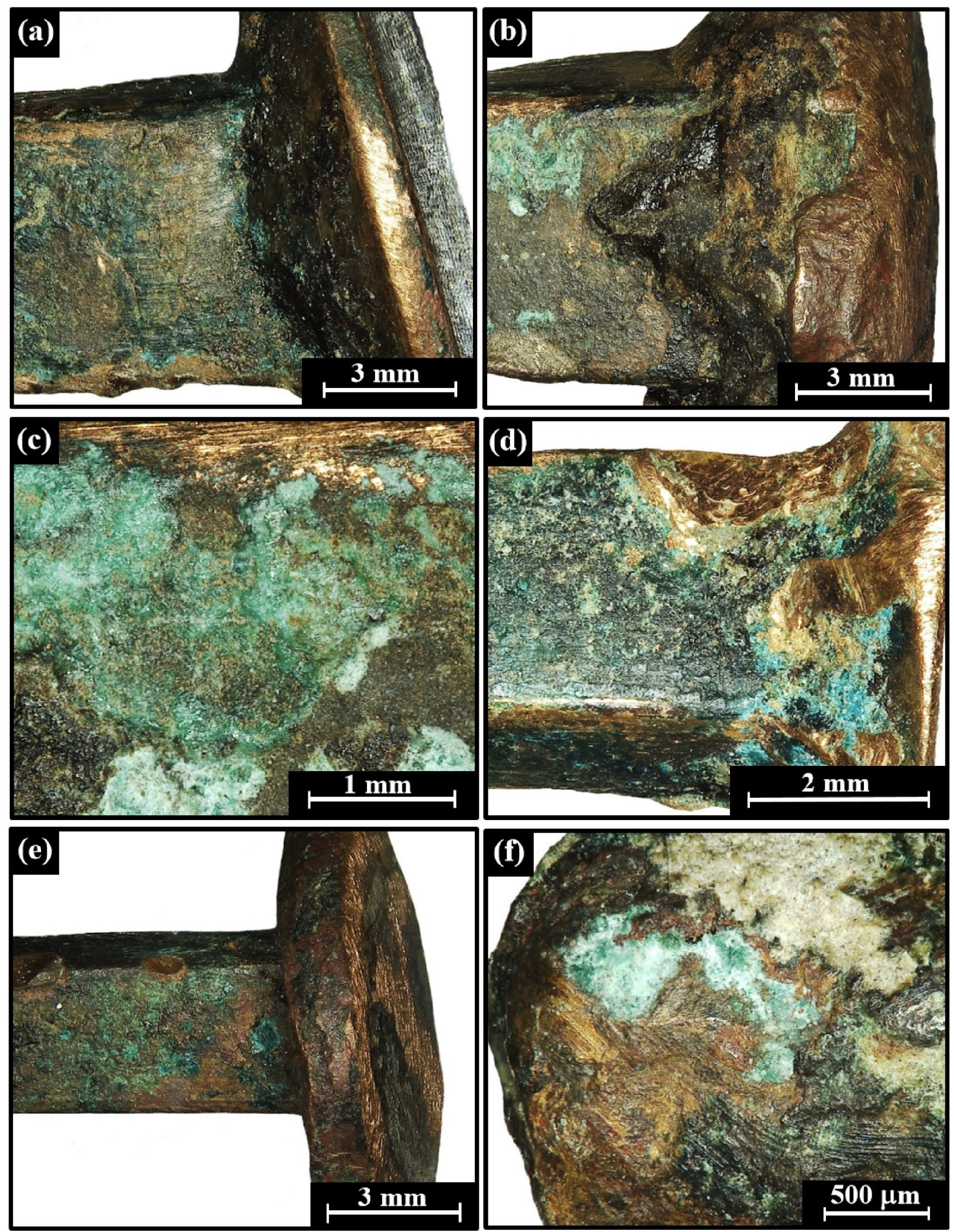

Fig. 8 Multifocal LM images of the copper spikes and copper nails: a the head and upper shank of spike no. 1 (the bright areas are exposed exposed metal (bright upper area) at the surface of spike no. 2 ; $\mathbf{d}$ the head of nail no. 1; $\mathbf{e}$ the head and upper shank of nail no. 2; and $\mathbf{f}$ the external surface of the lower shank tip covered with oxide 

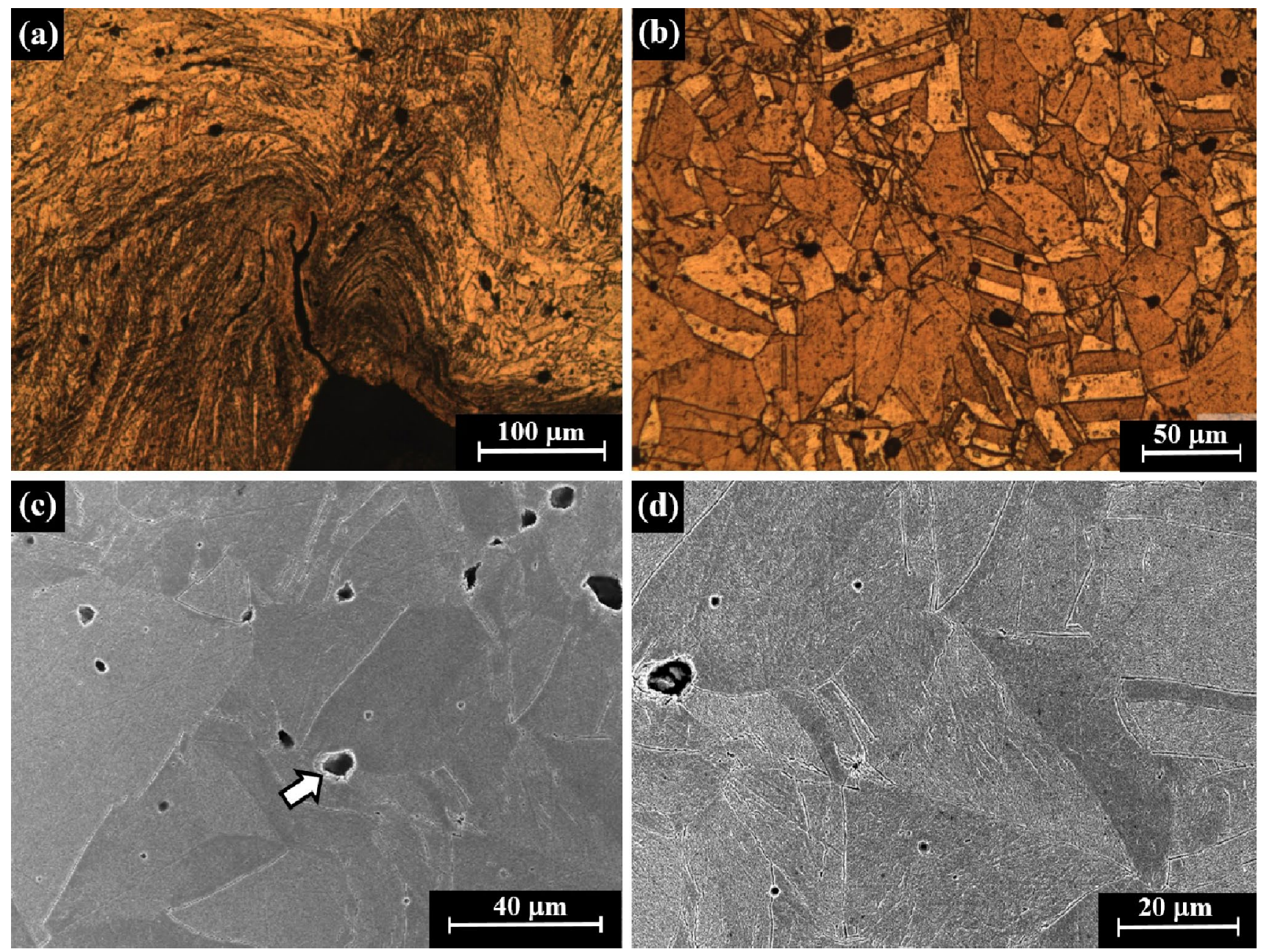

Fig. 9 Metallographic images of copper spike no. 1 (after etching): a head and upper shank of the spike, with the presence of slip bands (LM, L-CS); b grains with annealing twins and slag inclusions rich in

$\mathrm{Cu}, \mathrm{Pb}, \mathrm{As}, \mathrm{Bi}$ and $\mathrm{O}$ at the shank (LM, T-CS); $\mathbf{c}$ and d SEM images of the grains with some dark inclusions (dark circles at the shank, for example, the typical inclusion marked with an arrow in (c), L-CS)

aspects of ship construction and technology of the period, for example skills and past metallurgical knowledge, craft techniques, industrial production and adoption of materials [e.g. 15, 30, 37, 56]. Furthermore, typological, physical and chemical characterization of different fastenings (bolts, nails and other remains) has been very valuable in estimating the date and provenance of unidentified shipwrecks, hence contributing valuable information to the shipwreck sites [57]. The current study of the fastenings from the Molyneux boat provided additional information concerning its construction, life span and history.

The copper fastenings used in the construction of the boat were well preserved, but were covered with green, turquoise, yellow, brown and black minerals, which indicates a long-term corrosion process. The different corrosion products observed on the external surface of the copper fastenings can be assessed by the surface composition [41]. For example, the green and turquoise minerals may

be brochantite cupric sulphates, or paratacamite [58, p. 401]. The copper fastenings were composed of 96.5-99.0 wt $\% \mathrm{Cu}$. However, $\mathrm{Zn}, \mathrm{Si}, \mathrm{Fe}, \mathrm{Pb}, \mathrm{Sn}, \mathrm{As}, \mathrm{Bi}, \mathrm{Sb}$ and $\mathrm{Ag}$ were also detected (Table 2, XRF results). These minor elements may be considered as impurities, however some of them, such as $\mathrm{Pb}$, may have been added deliberately to improve the alloy properties [30, p. 191, 59]. Chemical analysis of archaeological objects may serve as a relative dating tool, since the presence of some elements and their concentrations could be related to material culture and technological abilities [37, p. 625]. At the beginning of the nineteenth century, traditional handmade nails were still common [56, p. 134]. However, during the century handmade nails were gradually replaced by industrial machinemade nails. Following various technological inventions, during the second half of the nineteenth century, industrial nails became more common [14, pp. 66-68, 60, pp. 38-39, 61 , pp. 56-57, 62]. 

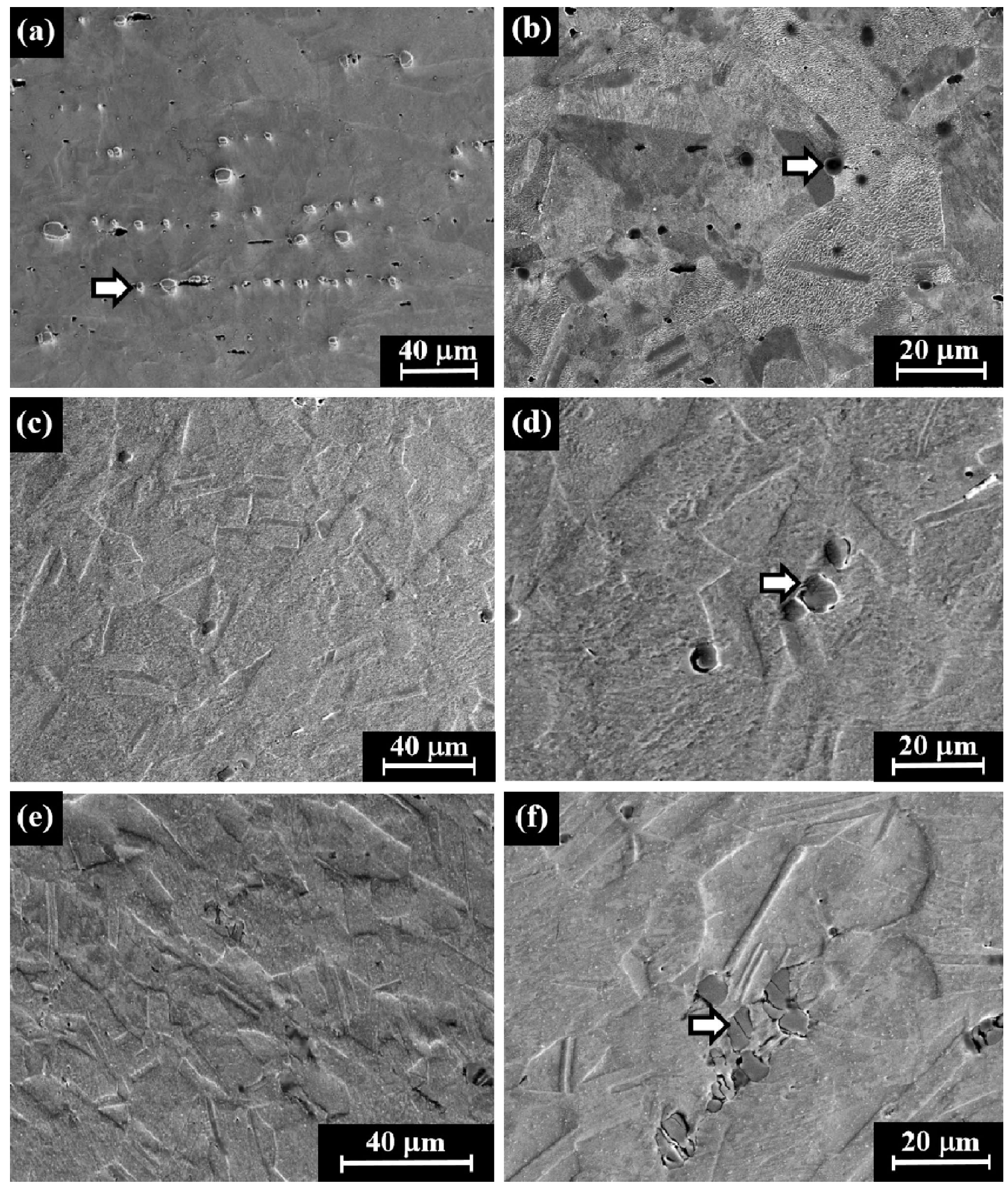

Fig. 10 Metallographic SEM images of copper nails nos. 1-3 (after etching): a shank with many slag inclusions arranged in strings, rich in $\mathrm{Cu}, \mathrm{Pb}, \mathrm{As}, \mathrm{Bi}$ and $\mathrm{O}$ (nail no. 1, round partials such as the one marked with an arrow, L-CS); $\mathbf{b}$ grains with annealing twins and slag inclusions (nail no. 1, shank, L-CS); c grains with annealing twins

at the shank (nail no. 2, L-CS); d grains with some dark inclusions (shank of nail no. 2, L-CS, one typical inclusion is marked with an arrow); e grains with annealing twins at the shank (nail no. 3, T-CS); and $\mathbf{f}$ group of slag round inclusions (dark circles, white arrow) at the shank (nail no. 3, T-CS) 

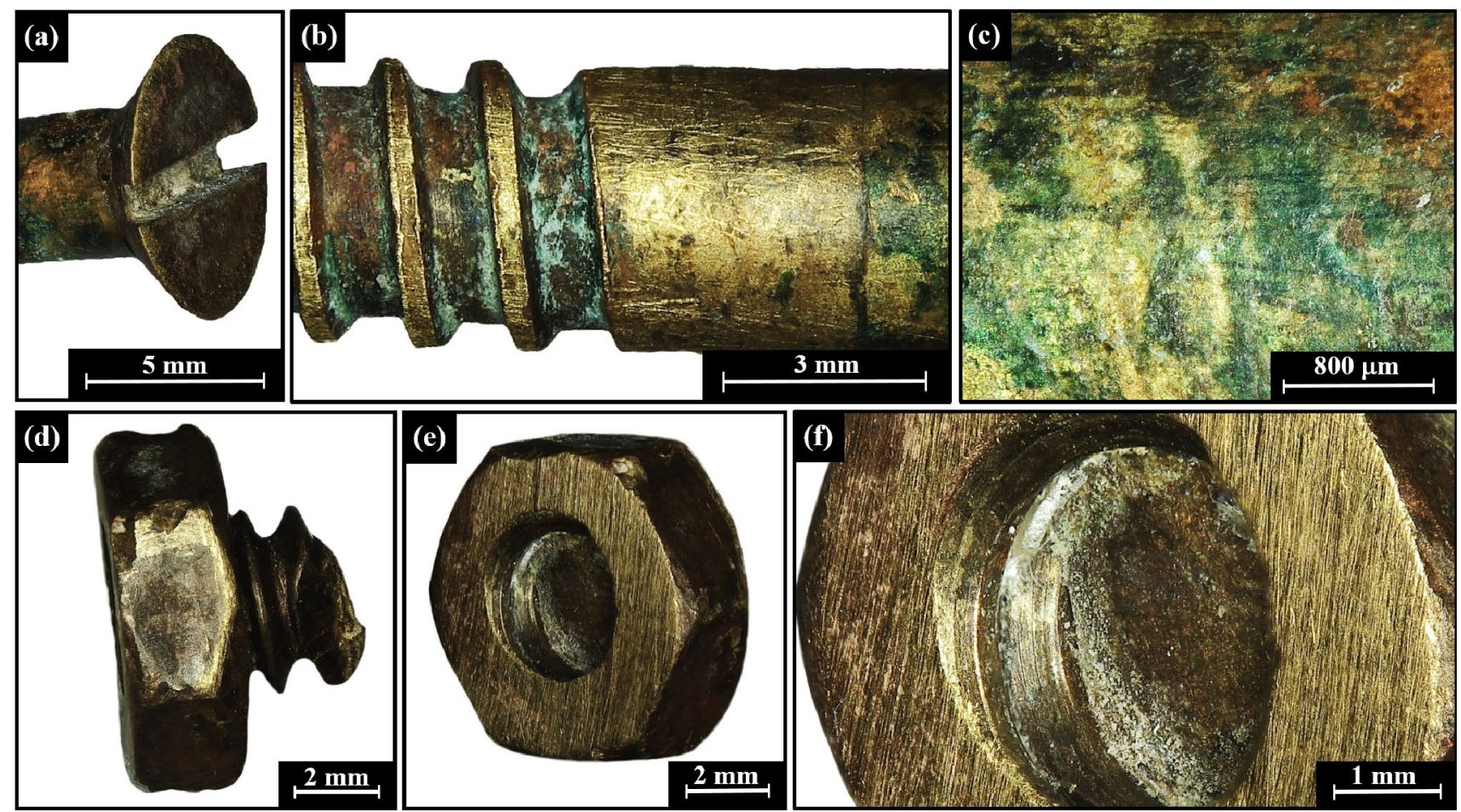

Fig. 11 Multifocal LM images of the brass screws and brass nut no. 2: a screw no. 1's head; b the shank's thread (left side of image); $\mathbf{c}$ the external surface of the shank covered with oxide, $\mathbf{d}$ and $\mathbf{e}$ screw no. 2 and nut no. 2 ; and $\mathbf{f}$ higher magnification of the nut showing machining marks

Bolts were also subjected to such kind of technological changes since the last quarter of eighteenth century. The introduction of machinery technologies for industrial production of fastenings was a gradual experience. This industrial transition can be appreciated in early-nineteenth-century shipwrecks, where the coexistence of fastenings made by both traditional and novel manufacturing techniques can be recorded. On the other hand, a wide range of technological experimentation and the limited use of machines were developed over the decades since then, long before a complete machine-made nail was produced. Moreover, differences in industrial trajectories of USA and European countries, and also between techniques applied for producing copper base and iron fastenings, should also be considered when evaluating metals that were used for nautical applications from the late eighteenth to mid-nineteenth centuries [26, p. 273].

Based on their shape, various dimensions, composition and microstructure (the presence of slip bands in Fig. 9a and grains with annealing twins in Fig. 9b), the copper fastenings from the Molyneux's boat were probably produced by a traditional process of cyclic hammering and annealing [49, pp. 73-74, 50, pp. 94-96, 51, pp. 369-370, 63, pp. 726-728, 64 , p. 164]. The recrystallized grains and annealing twins could also stand for a hot plastic deformation process, where the metal was worked above its recrystallization temperature
$[59,64$, p. $726,65,66]$. The presence of arsenic, silver and bismuth impurities is characteristic of copper smelted in Britain in the late eighteenth and early nineteenth centuries $[67$, p. 32, 68, p. 50]. Therefore, it is suggested that these copper fastenings were probably manufactured during the first half of the nineteenth century. However, even if the characteristics of the copper fastening are coherent with British $\mathrm{Cu}$ exploited at this period, their exact manufacturing date cannot be exclusively assumed from this data.

The brass screw type of no. 1 was patented by T.J. Sloan in 1848 [69]. Screws nos. 1 and 2, and nuts nos. 1 and 2, were made of brass (59.6-66.9 wt $\% \mathrm{Cu}$ and 29.7-39.5 wt $\%$ $\mathrm{Zn}$ ) (XRF results, Table 2). The green and turquoise minerals observed on the surface of the screws (Fig. 11) indicate a long-term corrosion process. A uniform distance between the teeth of the helical ridge at the lower part of the screw's shank was observed, typical of screws produced by an industrial process (Figs. 11a-b, 12a-b). Based on the microstructural examination, the bolt's thread was formed through plastic deformation, probably by thread rolling (Fig. 12d-f). In contrast, based on the observed machining tool marks and flow line pattern of the microstructure at the female thread (Figs. 3c-d, 6, 11f and 12d-f), the hexagonal nuts were produced by a machining process such as thread cutting. Production by precision machinery became widespread during the 1840s [70, p. 622, 71, p. 418]. Based on 

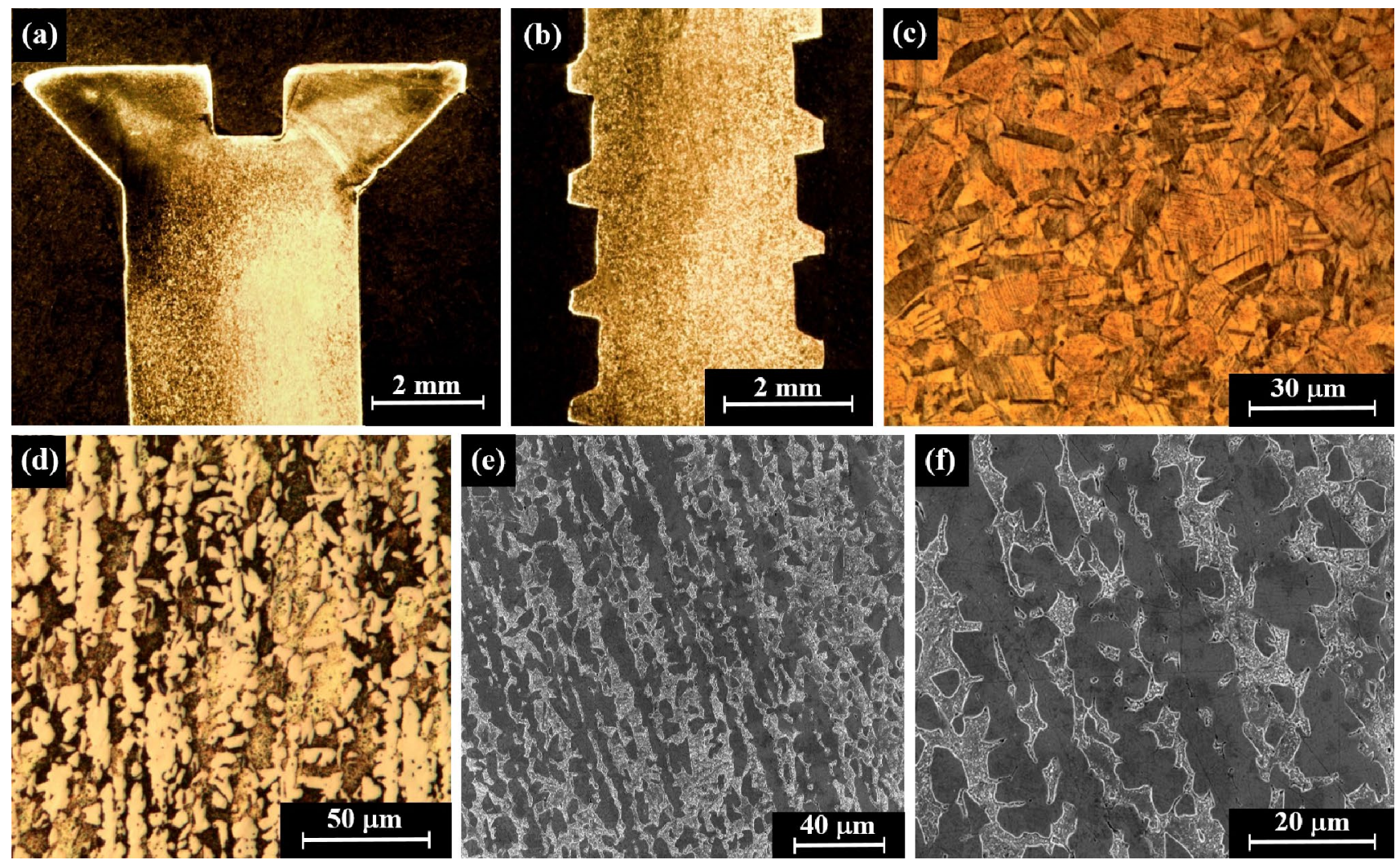

Fig. 12 Metallographic images of brass screw no. 1 and brass nut no. 2 (after polishing and etching): a metallographic specimen of the screw's head and upper shank (macroscopic view, L-CS); b macro- scopic view of the shank's thread; c microscopic view of the screw's shank, showing $\alpha$-brass phase with twin (LM, L-CS); $\mathbf{d}$ microscopic view of the nut (LM, L-CS); e and $\mathbf{f}$ SEM image of the nut (L-CS) the tapered shaft, even threads, centred slot and the pointed tip, and given its composition, screw no. 1 was most probably a post- 1848 product $[69,70$, p. 622,71, p. 418$]$. This is consistent with the brass composition of other ship finds from the period [72, p. 4].

In 1841, J. Whitworth developed a uniform system for standardization of threads of screw bolts, which was adopted as the British Standard system. The uniform distance between the teeth of the helical ridge of bolt no. 1 (Fig. 3), right-handed thread Whitworth 5/16"-18, suggests that was manufactured by an industrial process after $1841[38$, p. 96,73 , p. 67,74 , p. 330,75 , p. 20]. Based on the microstructure, bolt 1 was probably produced by thread rolling, a process patented in the last quarter of the nineteenth century. This bolt was made of a ferrous alloy (up to $99.6 \mathrm{wt} \% \mathrm{Fe}$ based on the XRF analysis and $97.7 \mathrm{wt} \%$ Fe based on the SEM-EDS analysis of the bolt's bulk) and had a carbon content of $0.1-0.2 \mathrm{wt} \%$ C. Its microstructure contains equiaxed ferrite grains with pearlite islands (Fig. 4a, b and d), typical of modern low-carbon steel. This indicates that the steel of bolt no. 1 was most probably produced by the Bessemer converter, invented by $\mathrm{H}$. Bessemer in 1856. The inexpensive Bessemer process enabled the mass production of steel for the first time. The Bessemer process produced a low-carbon steel, which usually contained $0.1-0.2 \mathrm{wt} \% \mathrm{C}[10$, pp. 223, 226, 11, pp. 164-165, 76, pp. 2776-2777, 77, p.789, 78, p. 454].

Considering its bright grey shiny metallic surface, and its surface composition (up to $69.0 \mathrm{wt} \% \mathrm{Zn}$, Table 2), the bolt was galvanized [17, p. 82, 79, pp. 34-38]. The use of a molten zinc bath to galvanize iron objects, such as sheets, in order to protect them against corrosion, was developed by I. M. Sorel in 1836 and patented in 1837 . In the same year, $\mathrm{H}$. W. Crawford also patented the process $[17$, p. 82]. Considering that the material of bolt no. 1 was produced by the Bessemer process, and that it was thread-rolled, it was most probably manufactured after the mid-nineteenth century. Although there is no evidence of any maintenance work done on the boat after it was built in 1836, galvanized bolts (such as bolt no. 1) and the brass screws suggest they were added at a later stage in the boat's life. Therefore, it is suggested that the boat was originally built using copper fastenings and other metal fastenings were added later during minor refitting. 


\section{Conclusions}

Research conducted on the boat built in England in 1836, and used in an expedition by Lieutenant Molyneux of the Royal Navy in 1847 , shows diverse manufacturing techniques and dates for the various fastenings: the copper spikes and nails were most probably made by a hand-forging process and intensively hammered and subsequently annealed into their final shape; the screws and hexagonal nuts were made of brass containing about $36 \mathrm{wt} \% \mathrm{Zn}$ and were probably a post- 1848 product based on their shape, microstructure examination and their manufacturing process; and the bolt was made of low-carbon steel produced by the Bessemer process, shaped by plastic deformation and galvanized, thus most probably manufactured after 1856 . Therefore, it is suggested that the boat was originally built using copper nails; and the brass screws and galvanized bolts were added later during minor refitting, perhaps after the 1847 expedition.

Acknowledgements The authors are grateful to Y. Eisenberg and R. Haikin of the Dead Sea Works, Israel, for their valuable assistance; to A. Vaze and M. Cohen of the University of Haifa, for their contributions; and to J.B. Tresman for the English editing. Special thanks go to the anonymous reviewers for their valuable comments and suggestions.

\section{References}

1. H.C. Folkard, The Sailing Boat: A Treatise on English and Foreign Boats, Descriptive of Various Forms of Boats and Sails of Every Nation with Practical Directions for Sailing Management (Longman, Green, and Roberts, London, 1863)

2. J.E. Boggis, Down the Jordan in a Canoe (Society for Promoting Christian Knowledge, London, 1939)

3. H. Goren, Dead Sea Level: Science (Exploration and Imperial Interests in the Near East. IB Tauris, London, 2011)

4. D.J. Lyon, The Sailing Navy List: All the Ships of the Royal Navy - Built, Purchased and Captured, 1688-1855 (Conway Maritime Press, London, 1993)

5. B. Warlow, Ships of the Royal Navy: The Complete Record of all Fighting Ships of the Royal Navy from the 15th Century to the Present (Chatham Publishing, London, 2010)

6. R.M. Steward, Boatbuilding Manual, 4th edn. (International Marine/ Ragged Mountain Press, Camden House Publisher, Boydell and Brewer, Suffolk, 1994)

7. M.L. Lang, L. Bejo, J. Szalai, Z. Kovacs, Orthotropic strength and elasticity of hardwoods in relation to composite manufacture, part I. Orthotropy of shear strength. Wood Fiber Sci. 32(4), 502-519 (2000)

8. E.O. Eriksen, Holy Land Explorers (Franciscan Printing Press, Jerusalem, 1989)

9. T.H. Molyneux, Expedition to the Jordan and the Dead Sea. J. Roy. Geograph. Soc. 18(2), 104-130 (1848)

10. J. Le Coze, Purification of iron and steels a continuous effort from 2000 BC to AD 2000. Mater. Trans. (JIM) 41(1), 219-232 (2000)

11. R.F. Tylecote, A History of Metallurgy (Institute of Materials, London, 1992)

12. I. Voiculescu, V. Geantă, A. Stern, D. Ashkenazi, M. Cohen, D. Cvikel, Iron-bound deadeyes from the nineteenth-century
Akko Tower wreck, Israel: Metallurgical investigation of the manufacturing technology. Metallogr. Microstruct. Anal. 6(2), 106-125 (2017)

13. T. Wells, Nail chronology: the use of technologically derived features. Histor. Archaeol. 32(2), 78-99 (1998)

14. W.H. Adams, Machine cut nails and wire nails: American production and use for dating 19th-century and early-20th-century sites. Hist. Archaeo. 36(4), 66-88 (2002)

15. D. Cvikel, T. Ben-Artzi, D. Ashkenazi, N. Iddan, A. Stern, Y. Kahanov, A box containing carpenter's accessories from the Akko 1 Shipwreck, Israel: Archaeometallurgical analysis of surviving ironwork. Archaeometry 58(3), 427-440 (2016)

16. N. Isaacs, Nails in New Zealand 1770 to 1910 . Construc. Hist. 24, 83-101 (2009)

17. A.C. Downs, Zinc for paint and architectural use in the 19th Century. Bull. Assoc. Preserv. Tech. 8(4), 80-99 (1976)

18. D.H. Spennemann, Stanislas Sorel's zinc-based paints. Transac. IMF 98(1), 8-13 (2020)

19. I.D. MacLeod, J. Beng, The contribution of alloy composition to the fate of foundered vessels. Stud. Conserv. 45(1), 124-127 (2000)

20. P. Valério, E. Voráčová, R.J.C. Silva, M.D.F. Araújo, A.M.M. Soares, A.M. Arruda, C. Pereira, Composition and microstructure of Roman metallic artefacts of Southwestern Iberian Peninsula. Appl. Phys. A 121(1), 115-122 (2015).

21. M.E. Callow, J.A. Callow, Marine biofouling: a sticky problem. Biologist 49(1), 1-5 (2002)

22. J.M. Bingeman, J.P. Bethell, P. Goodwin, A.T. Mack, Copper and other sheathing in the Royal Navy. Intern. J. Naut. Archaeol. 29(2), 218-229 (2000)

23. M. Staniforth, The introduction and use of copper sheathingA history. Bull. Aust. Instit. Maritime Archaeol. 9(1), 21-48 (1985)

24. R.J. Sinko, C.R. Brooks, Microstructural analysis of brass and zinc nails from the wreckage of a sailing ship. Mater. Charact. 29(2), 259-265 (1992)

25. R. Cock, 'The finest invention in the world': the Royal Navy's early trials of copper sheathing, 1708-1770. Mariner's Mirror 87(4), 446-459 (2001)

26. N.C. Ciarlo, G. Maxia, M. Rañi, H. De Rosa, R.G. Mauri, G.V. Lombarte, Craft production of large quantities of metal artifacts at the beginnings of industrialization-Application of SEM-EDS and multivariate analysis on sheathing tacks from a British transport sunk in 1813. J. Archaeol. Sci. Rep. 5, 263-275 (2016)

27. H.Y. Atay, G. Uslu, Y. Kahmaz, Ö. Atay, Investigations of microstructure and mechanical properties of brass alloys produced by sand casting method at different casting temperatures. In IOP Conference Series: Mater. Sci. Eng. 726(1), 012018. IOP Publishing, Bristol (2020)

28. M. Di Fazio, A.C. Felici, F. Catalli, M.T. Doménech-Carbó, C. De Vito, A. Doménech-Carbó, Solid-state electrochemical characterization of emissions and authorities producing Roman brass coins. Microchem. J. 152, 104306 (2020)

29. B. Baretzky, M. Friesel, B. Straumal, Reconstruction of historical alloys for pipe organs brings true baroque music back to life. MRS Bull. 32(3), 249-255 (2007)

30. M. Cohen, D. Ashkenazi, Y. Kahanov, A. Stern, S. Klein, D. Cvikel, The brass nails of the Akko Tower wreck (Israel): Archaeometallurgical analyses. Metall. Microstruct. Anal. 4(3), 188-206 (2015)

31. G. Pantazopoulos, A. Vazdirvanidis, Characterization of the microstructural aspects of machinable-phase brass. Microscopy Anal., 13-16 (2008)

32. D. Ashkenazi, D. Cvikel, N. Iddan, E. Mentovich, Y. Kahanov, M. Levinshtein, Archaeometallurgical study of the brass cases from the Akko 1 shipwreck. J. Archaeol. Sci. 38(9), 2410-2419 (2011) 
33. D. Ashkenazi, D. Cvikel, A. Stern, S. Klein, Y. Kahanov, Metallurgical characterization of brass objects from the Akko 1 shipwreck. Israel. Mater. Character. 92, 49-63 (2014)

34. D. Cvikel, D. Ashkenazi, V. Spiegelman, A. Stern, S. Klein, G. Rimer, Flintlock brass fittings from the 19th-century Akko 1 shipwreck. Israel. Arms Armour 14(2), 138-164 (2017)

35. D. Ashkenazi, D. Cvikel, M. Holtzman, D. Bershadski, A. Stern, S. Klein, Y. Kahanov, The Dor C shipwreck, Israel: metallurgical analysis and its contribution to the ship characterization. Archaeol. Anthropol. Sci. 9(3), 431-445 (2017)

36. D. Cvikel, M. Cohen, A. Inberg, S. Klein, N. Iddan, D. Ashkenazi, Metallurgical characterization of brass sheet from the 19th-century Akko Tower Wreck (Israel). Mater. Character. 131, 175-187 (2017)

37. D. Ashkenazi, I. Misgav, R. Issachar, S. Klein, D. Cvikel, New insights into brass nails from the 19th-century Akko Tower Wreck (Israel): Metallurgical characterization. J. Alloys Compounds 771, 614-628 (2019)

38. M. McCarthy, Ship's Fastenings from Sewn Boat to Steamship (Texas A\&M University Press, College Station, Texas, 2005)

39. J.R. Steffy, Wooden Ship Building and the Interpretation of Shipwrecks (Texas A\&M University, College Station, 1994)

40. C. Bottaini, A. Brunetti, R. Bordalo, A. Valera, N. Schiavon, Non-destructive characterization of archeological Cu-based artifacts from the early metallurgy of southern Portugal. Archaeol Anthropol. Sci. 10(8), 1903-1912 (2018)

41. D. Ashkenazi, D. Cvikel, A journey into the microstructure: Using a multifocal 3D digital light microscope to study archaeological artefacts retrieved from shipwrecks. Digit. Appl. Archaeo. Cultur. Herit. 16, e00129 (2020)

42. D.E. Newbury, N.W. Ritchie, Is scanning electron microscopy/ energy dispersive X-ray spectrometry (SEM/EDS) quantitative? Scanning 35(3), 141-168 (2013)

43. D. Neff, P. Dillmann, L. Bellot-Gurlet, G. Beranger, Corrosion of iron archaeological artefacts in soil: characterisation of the corrosion system. Corr. Sci. 47(2), 515-535 (2005)

44. M. Saheb, D. Neff, J. Demory, E. Foy, P. Dillmann, Characterisation of corrosion layers formed on ferrous archaeological artefacts buried in anoxic media. Corr. Eng. Sci. Tech. 45(5), 381-387 (2010)

45. A.P. Reynolds, W. Tang, M. Posada, J. DeLoach, Friction stir welding of DH36 steel. Sci. Tech. Weld. Join. 8(6), 455-460 (2003)

46. R. Dąbrowski, J. Pacyna, J. Krawczyk, New high hardness MnCr-Mo-V tool steel. Archives Metallurgy Mater. 52(1), 87-92 (2007)

47. V. Singh, M.R. Singh, Steelmaking in India-new evidence from microscopic and archaeometallurgical analysis from middle Ganga plain. Balirajgarh. J. Microscopy 276(3), 128-135 (2019)

48. M. Milad, N. Zreiba, F. Elhalouani, C. Baradai, The effect of cold work on structure and properties of AISI 304 stainless steel. J. Mater. Proc. Tech. 203(1-3), 80-85 (2008)

49. L.E. Samuels, The metallography of some copper-alloy relics from HMS Sirius. Metallography 16, 69-79 (1983)

50. L.E. Samuels, Australia's contribution to archaeometallurgy. Mater. Charact. 29, 69-109 (1992)

51. M.L. Wayman, R.R. Smith, C.G. Hickey, M.J.J. Duke, The analysis of copper artifacts of the copper Inuit. J. Archaeol. Sci. 12(5), 361-375 (1985)

52. G. Philip, P.W. Clogg, D. Dungworth, S. Stos, Copper metallurgy in the Jordan Valley from the third to the first millennia BC: chemical, metallographic and lead isotope analyses of artefacts from Pella. Levant 35(1), 71-100 (2003)

53. D.E. Miller, J. Kinahan, The metallurgical analysis of copper beads and ore from archaeological sites in central Namibia. Commun. Geo. Survey Namibia 8, 67-79 (1993)
54. C. Canovaro, I. Angelini, G. Artioli, P. Nimis, E. Borgna, Metal flow in the late Bronze Age across the Friuli-Venezia Giulia plain (Italy): new insights on Cervignano and Muscoli hoards by chemical and isotopic investigations. Archaeol. Anthropol. Sci. 11(9), 4829-4846 (2019)

55. D.I. MacLeod, The surface analysis of a brass plate "Ludwig Leichhardt 1848"' and assessment of authenticity (Collections Management and Conservation, Western Australian Museum, Perth, 2006)

56. N.C. Ciarlo, A. Argüeso, Archaeometric and archaeometallurgical studies on historical shipwrecks: research experiences in Argentina. J. Marit. Archaeol. 14(1), 127-150 (2019)

57. N.C. Ciarlo, Historical shipwrecks, Archaeometry of. In: C. Smith (editor), Encyclopaedia of Global Archaeology, pp. 59-76. 2nd Ed. (Springer, New York, 2019)

58. A. Inberg, D. Ashkenazi, M. Cohen, N. Iddan, D. Cvikel, Corrosion products and microstructure of copper alloy coins from the Byzantine-period Ma'agan Mikhael B shipwreck. Israel. Microchem. J. 143, 400-409 (2018)

59. M. McAllister, Preliminary analysis of copper alloy fastenings from an unidentified shipwreck in Koombana Bay, Western Australia. Bull. Australasian Inst. Maritime Archaeol. 36, 36-43 (2012)

60. L. McNally, Technical advance and stagnation: the case of nail production in nineteenth-century Montreal. Mater. Cult. Rev. 36(1), 38-48 (1992)

61. A. Middleton, Nail chronology: the case of Te Puna Mission Station. Aust. Hist. Archaeol. 23, 55-62 (2005)

62. M.K. Phillips, "Mechanic Geniuses and Duckies," a revision of New England's cut nail chronology before 1820. APT Bull. J. Pres. Tech. 25(3/4), 4-16 (1993)

63. H.M. De Rosa, N.C. Ciarlo, M.C. Lucchetta, P. Marino, Coppers from the battle of Trafalgar: metallurgical analysis of structural fastenings from the French ships Fougueux (1785-1805) and Bucentaure (1804-1805). Procdia Mater. Sci. 8, 722-731 (2015)

64. A. Viduka, S. Ness, Analysis of some copper-alloy items from HMAV Bounty wrecked at Pitcairn Island in 1790. In: Metal O4: Proceedings of the International Conference on Metals Conservation, pp. 160-169 (2004)

65. N.C. Ciarlo, M.C. Lucchetta, H. De Rosa, Análisis metalográfico y químico de un conjunto de artefactos recuperados del naufragio Triunfante (1756-1795), Golfo de Rosas (Cataluña, España). In: Nieto, X., Pujol i Hamelink, M., Vivar, G. (eds.), El vaixell Triunfante: Una fita de la ciència i de la tècnica del segle XVIII. Monografies del Centre d'Arqueologia Subaquàtica de Catalunya No. 12, pp. 159-171. Museu d'Arqueologia de Catalunya, Girona (2013).

66. I.D. MacLeod, M. Pitrun, Metallography of copper and its alloys recovered from nineteenth century shipwrecks. In: Kuppuram, G., Kumudamani, K. (editor), Marine Archaeology. The Global Perspectives. (New Gyan Offset Press, New Delhi, 1996), pp. 347-356

67. J. Whitewright, J. Satchell, The Archaeology and History of the Flower of Ugie, Wrecked 1852 in the Eastern Solent.Bar British Series 551. (Archaeopress, Oxford, 2011)

68. J. Whitewright, J. Satchell, The Maritime Archaeology of Alum Bay.Bar British Series 608 (Archaeopress, Oxford, 2014)

69. T.J. Sloan, Improvement in wood-screws. U.S. Patent no. USRE107E (1848)

70. R.A. Church, Nineteenth-century clock technology in Britain, the United States, and Switzerland. Econ. Hist. Rev. 28(4), 616-630 (1975)

71. N. Rosenberg, Technological change in the machine tool industry, 1840-1910. J. Econ. Hist. 23(4), 414-443 (1963)

72. D. Hallam, The Leichhardt Nameplate - A Report on Authenticity Testing (National Museum of Australia, Canberra, 2006) 
73. R.C. Brooks, Standard screw threads for scientific instruments. Part I: Production techniques and the Filière Suisse. Hist. Technol. Int. J. 5(1), 59-76 (1988)

74. M. McCarthy, R. Garcia, Screw threads on the SS Xantho engine: a case of standardisation in 19th century Britain. Inter. J. Naut. Archaeol. 33(2), 330-337 (2004)

75. B. Sinclair, At the turn of a screw: William Sellers, the Franklin Institute, and a standard American thread. Tech. Cult. 10(1), 20-34 (1969)

76. M. De Bouw, I. Wouters, J. Vereecken, L. Lauriks, Iron and steel varieties in building industry between 1860 and 1914-A complex and confusing situation resolved. Constr. Build. Mater. 23(8), 2775-2787 (2009)

77. G. Lesiuk, M. Szata, M. Bocian, The mechanical properties and the microstructural degradation effect in an old low carbon steels after 100-years operating time. Arch. Civ. Mech. Eng. 15(4), 786-797 (2015)

78. Sparks, S.P., Evaluation of iron and steel in historic bridges. In: D. D’Ayala, E. Fodde (eds.), Structural Analysis of Historic Construction: Preserving Safety and Significance. (CRS Press, Taylor \& Francis Group, London, 2008), pp. 451-458.

79. F.B. Mainier, V. Perassolli, Ship hull corrosion caused by default and lack of maintenance on the impressed current cathodic protection. J. Eng. (IOSRJEN) 4(2), 34-38 (2014)

Publisher's Note Springer Nature remains neutral with regard to jurisdictional claims in published maps and institutional affiliations. 